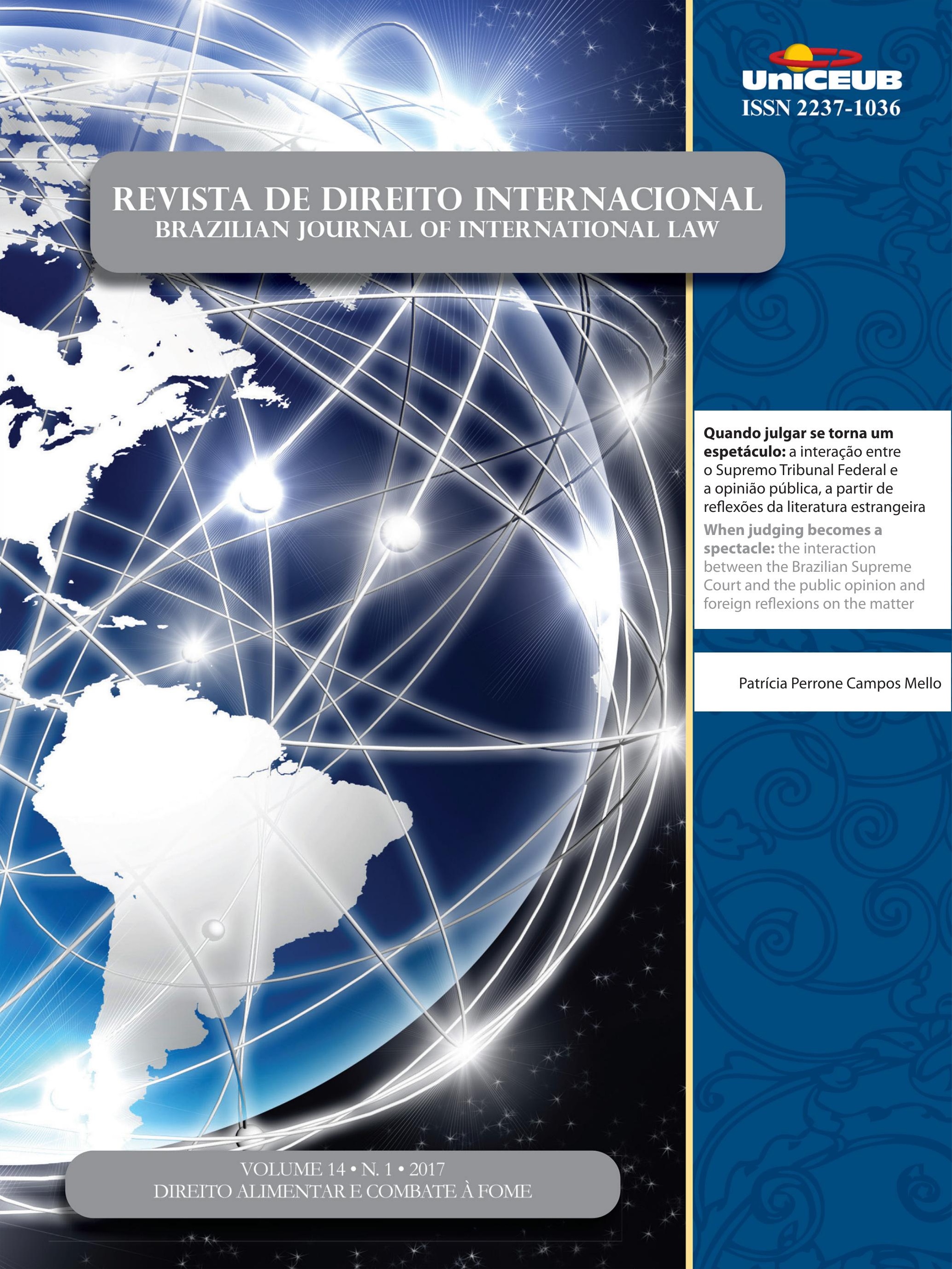




\section{Sumário}

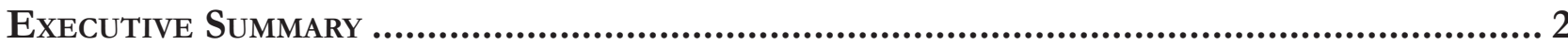

Daniel Balaban

Crônicas Sobre o Direito Alimentar e o Combate À Fome .............................................. 5

South-South Food and Nutrition Security promotion: the Brazilian experience

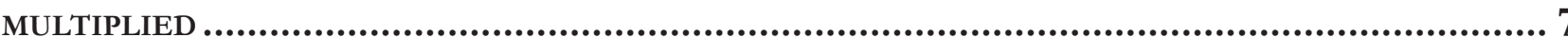

João Almino

Access to Food as a Human Right: Brazil, WFP and South-South Cooperation .......10 Carlos R. S. Milani

Dossiê temático: Direito Alimentar e Combate à Fome 13

WFP'S ROLE IN BUILDING SUSTAINABLE BRIDGES BETWEEN THE RIGHT TO ADEQUATE FOOD AND THE FREEDOM FROM HUNGER 15

Christiani Amaral Buani e Bruno Valim Magalhães

Direito humano À ALIMENTAÇÃo, (IN) SEgURANÇA ALIMENTAR E DESENVOLVIMENTO: OS DESAFios à REALIZAÇão PROGRESSIVA Na AMÉrica LATINa

Sinara Camera e Rubia Wegner

STATE'S INTERNATIONAL RESPONSIBILITY FOR THE HUMAN RIGHT TO FOOD: IMPLEMENTATION IN BRAZIL THROUGH AGROECOLOGY

Paula F. Strakos e Michelle B.B. Sanches

NegotiatiNg agRiCULtURE IN THE WORLD TRADE ORgANIZATION: FOOD SECURITY AS A NON-TRADE CONCERN.

Ana Luísa Soares Peres e Letícia de Souza Daibert

QUANDO HABITAR CORRESPONDE AO DIREITO HUMANO À ALIMENTAÇÃO

Fernanda Viegas Reichardt e Maria Elisa de Paula Eduardo Garavello 
The ROLE OF SUSTAINABLE LEARNING POLICIES ON THE FIGHT AGAINST

HUNGER IN ADULT EDUCATION.

Hiran Catuninho Azevedo

O DIREITO HUMANO E FUNDAMENTAL À ALIMENTAÇÃo ADEQUADA E À CONDIÇÃo

FEMININA NO PROGRAMA BOLSA FAMÍlIA: EMPODERAMENTO ÀS AVESSAS?

Rosalice Fidalgo Pinheiro e Laura Garbini Both

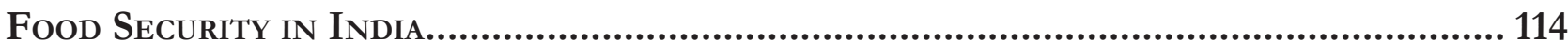

Ranjana Ferrão

SEguranÇA ALIMENTAR E A GOVERnANÇA ECONÔMICA GLOBAL

Danielle Mendes Thame Denny, Douglas de Castro, Alexandre Ricardo Machado, José Valverde Machado Filho e Gabrielle Fontes Witt

Outros Artigos.

The legal implications of the Draft Universal Declaration of the Rights of MANKIND

Catherine Le Bris

Litigating Indigenous Dispossession in THE Global Economy:

Law's Promises and Pitfalls................................................................................ 165

Charis Kamphuis

UNE DÉFINITION DU PRÉ-INVESTISSEMENT CONFORME À L'APPROCHE FRANÇAIS MAIS CONTRAIRE À L'APPROCHE AMÉRICAINE AU SEIN DES TRAITÉS BILATÉRAUX D'INVESTISSEMENTS IRANIENS

Peyman Dadras

CONFLITOS ENTRE REGULAÇÕES INTERNAS RELATIVAS À INTERNET E O DIREITO DO COMÉRCIO INTERNACIONAL: O PAPEL DA OMC PERANTE O SISTEMA DE COMPUTAÇÃO DA NUVEM ............238

Alice Rocha da Silva e Filipe Rocha Martins Soares

Prélèvement: origem, EVoluÇão e ocaso do Privilégio NAS SuCESSÕes INTERNACIONAIS NA FRANÇA

Fernando Pedro Meinero 
OS CONTRATOS INTERNACIONAIS DE FINANCIAMENTO E O CENTRO FINANCEIRO DE

Nova IorQue: CONSIDERAÇões SOBRE A AUTONOMIA DA VONTADE

Fernanda Torres Volpon

Mercosul e o Meio ambiente: ANÁlise da tUTELA REgional AMBIENTAL 284 Clarissa Ferreira Macedo D'Isep

Ainda (E uma Vez MAis) o SILÊNCIO QUe ENTOA O TRIUNFo De Lewis Carrol: A Regra N ${ }^{\circ} 42$ do Supremo Tribunal Federal

Thiago Aguiar Pádua e Bruno Amaral Machado

\section{A Natureza Jurídica do Sistema de Solução de Controvérsias da OMC} E DE SuAs Decisões: Solucionando um Imbróglio 316

Camila Capucio

Brics: Desafios do DESENVOLVIMENTO ECONÔMICO E SOCIOAMBIENTAI Magno Federici Gomes e Luís Eduardo Gomes Silva

REVER OU ROMPER COM VESTFÁLIA? POR UMA RELEITURA DA EFETIVA CONTRIBUIÇÃO DOS ACORDOS DE PAZ DE 1648 À CONSTRUÇÀO DO MODELO VESTFALIANO DE ESTADOS.

Luiz Magno Pinto Bastos Junior

Justiça de Transição EM SUA GÊNESE: A Alemanha Pós-NAZismo 378 Bruno Galindo

Quando JUlgar SE TORNa UM ESPETÁCulo: A INTERAÇão ENTRE o Supremo Tribunal Federal e a opinião pública, A PARTIR de REFlexões da LITERATURA ESTRANGEIRA

Patrícia Perrone Campos Mello

TolerânCia E refugio: um ENSAIO A PARTIR do ACORdo EU-TurQuia 425 Flávia Cristina Piovesan e Ana Carolina Lopes Olsen 


\title{
Quando julgar se torna um espetáculo: a interação entre o Supremo Tribunal Federal e a opinião pública, a partir de reflexões da literatura estrangeira *
}

\author{
When judging becomes a spectacle: the \\ interaction between the Brazilian Supreme \\ Court and the public opinion and foreign \\ reflexions on the matter
}

Patrícia Perrone Campos Mello **

\section{Resumo}

O ensaio procura demonstrar que o Legislativo e o Executivo podem não ser representativos da vontade popular; que o Supremo Tribunal Federal, não raro, julga de acordo com a vontade da maioria; e que esquemas tradicionais de separação de poderes precisam ser problematizados para que se compreenda a interação entre o STF e a opinião pública. Argumenta-se, ainda, que não apenas as decisões contramajoritárias, mas igualmente a decisões majoritárias do Supremo devem ser objeto de crítica. A tendência à espetacularização dos julgamentos da Corte e a forte exposição de seus membros à mídia torna-os vulneráveis ao contágio informacional, ao contágio reputacional e ao efeito manada. Com esse objetivo, o artigo recorre a estudos estrangeiros que explicam a interação entre cortes constitucionais e opinião pública; examina pesquisas de opinião sobre matérias decididas pelo Congresso Nacional e submetidas ao STF; analisa o julgamento de tais casos; e avalia as declarações dos ministros sobre a influência da opinião pública nos respectivos julgamentos.

Palavras-chave: Supremo Tribunal Federal. Jurisdição constitucional. Legitimidade democrática. Opinião pública. Mídia e imprensa. Espetáculo.

* Autora convidada

** Professora do Programa de Mestrado e Doutorado da Uniceub, Doutora e Mestre pela Universidade do Estado do Rio de Janeiro UERJ, Assessora de Ministro do Supremo Tribunal Federal, Procuradora do Estado. E-mail: patriciaperrone@uol.com.br

\section{Abstract}

The paper aims at demonstrating that Legislative and Executive powers can lack popular representation; that the Brazilian Supreme Court, not rarely, decides in accordance to the popular will; and that traditional division of powers schemes must be questioned in order to allow an accurate understanding of the interaction between the Court and Brazilian society. It also argues that not only countermajoritarian decisions of the Court may be monitored, but also the majoritarian ones. The media surveillance of the Brazilian Supreme Court and the over exposition of its justices to the press make them vulnerable to informational contagion, reputational contagion and cascades. With this goal, the paper presents foreign studies that explain 
the interaction between constitutional courts and public opinion; analyses public opinion polls on matters decided by the Brazilian Congress and submitted to its Supreme Court; studies the mentioned constitutional cases; and examines statements of Brazilian justices about the influence of public opinion over the Court's decisions.

Keywords: Brazilian Supreme Court. Constitutional jurisdiction. Democratic legitimacy. Public opinion. Media and press. Spectacle.

\section{INTRODUÇão}

Muito se tem debatido e escrito sobre os limites da atuação do Supremo Tribunal Federal. Discute-se até que ponto estaria o Tribunal legitimado a declarar a nulidade de atos produzidos pelos representantes eleitos pelo voto popular (integrantes do Legislativo e do Executivo), quando é composto por onze juízes que não foram eles próprios eleitos, mas meramente selecionados pelo Presidente da República e aprovados, após sabatina, pelo Senado federal.

Discute-se, ainda, se a superação do dogma do legislador negativo ${ }^{1}$ e a produção de decisões aditivas pela Corte $^{2}$ não implicariam uma clara violação ao processo democrático e ao princípio da separação dos poderes. A concepção de legitimidade que serve de base a tais questionamentos é clara: aqueles que a corroboram identificam a legitimidade da produção do Direito com o exercício de um mandato representativo. Segundo este critério, a voz do Executivo e a voz do Congresso expressam a vontade do povo e, por isso, devem prevalecer.

1 Segundo o dogma do legislador negativo, o Supremo Tribunal Federal deveria se limitar a proferir decisões que retirem do ordenamento normas incompatíveis com a Constituição. Não poderia, contudo, atuar como legislador positivo, acrescentando conteúdo ao ordenamento jurídico, quer com o propósito de compatibilizar o significado de normas infraconstitucionais com a Constituição, que com o objetivo de conferir efetividade a direitos previstos na Constituição e dependentes de regulamentação pelo legislador. Sobre a superação do referido dogma pela jurisprudência do STF, cf. BARROSO, Luís Roberto. O controle de constitucionalidade no direito brasileiro. São Paulo: Saraiva, 2004. p. 104-110 e 208-209.

2 As decisões de efeito aditivo ampliam o âmbito de incidência do texto da lei. As de efeitos substitutivos levam à substituição da disciplina prevista na norma por outra, compatível com o paradigma constitucional. Sobre o tema, v. MENDES, Gilmar Ferreira; COELHO, Inocêncio Mártires; BRANCO, Paulo Gustavo Gonet. Curso de direito constitucional. São Paulo: Saraiva, 2010. p. 1432-1435.
Pretende-se demonstrar, por meio deste ensaio, que a interação entre os diferentes poderes do Estado e a sociedade que pretendem normatizar é mais complexa do que o esquema tradicional de separação de poderes que habita o imaginário de tais críticos. A mera eleição pelo voto popular não assegura uma atuação efetivamente representativa e, portanto, legítima (segundo o critério acima), por parte das instâncias majoritárias. Por outro lado, o Supremo Tribunal Federal pode servir de espaço à expressão de pleitos majoritários, a despeito de não se compor de ministros eleitos. Como se verificará ao longo deste ensaio, é inadequado definir um critério estático e, sobretudo, formal — consistente na eleição pelo voto popular ou em uma concepção ortodoxa de separação dos poderes - para aferir a legitimidade de uma decisão. Todos os poderes falham, todos os poderes respondem perante a opinião pública ${ }^{3}$ e segui-la também envolve seus riscos.

Com tal objetivo, o artigo partirá de um exame das instâncias majoritárias, com o propósito de demonstrar que há, no direito constitucional brasileiro (e não só nele ${ }^{4}$ ), diversos mecanismos e incentivos para que tais instâncias não sejam perfeitamente representativas ${ }^{5}$. Demonstrar-se-á, em seguida, como e por que pleitos majoritários não acolhidos nas instâncias representativas podem encontrar caminho no Judiciário, especialmente no Supremo Tribunal Federal, o que tampouco significa que as decisões da Corte serão mais legítimas do que aquelas produzidas no Executivo e no Legislativo. Na sequência, o trabalho desenvolverá um estudo do processo de formação. Analisará o papel desempenhado pela imprensa, bem como a ação de mecanismos de contágio informacional e de contágio reputacional, que podem conduzir os tribunais - tanto quanto os demais poderes - à incompreensão de seus limites institucionais, ao populismo e ao erro.

3 Designa-se opinião pública o conjunto de ideias e de juízos partilhados pela maioria dos membros da sociedade sobre temas de interesse social. Esse é o conceito dominante na literatura consultada e empregado pelo dicionário Novo Aurélio NOVO Aurélio: o dicionário da língua portuguesa. Rio de Janeiro: Nova Fronteira, 1999. p. 1.449.

4 LAIN, Corinna Barrett. Upside-down judicial review. Social Science Research Network, [Rochester], 12 Jan. 2012. p. 11. Disponível em: $<$ http://ssrn.com/abstract=1984060>. Acesso em: 27 set. 2013.

5 Com a expressão "perfeitamente representativas" pretende-se aludir a uma efetiva correspondência entre o pensamento dominante na população e aquele resultante da deliberação das instâncias políticas majoritárias - Executivo e Legislativo. 


\section{As INSTÂNCIAS MAJORITÁRIAS PODEM NÃO SER REPRESENTATIVAS?}

Afirmar que as instâncias majoritárias podem não ser efetivamente representativas não constitui propriamente uma revelação no momento atual de nossa história constitucional. O ano de 2015 foi marcado por uma Presidente da República impedida pelo Congresso Nacional, por um Presidente da Câmara dos Deputados afastado e posteriormente cassado, por notícias de investigações criminais envolvendo o Presidente do Senado e pela descrença generalizada nas instituições majoritárias. Sem qualquer pretensão de exaurir as múltiplas causas responsáveis pelas disfunções do nosso sistema democrático, algumas dessas causas são de fácil identificação.

A primeira delas diz respeito ao mecanismo da representação. Não há dúvida de que a melhor forma de os cidadãos manifestarem sua vontade a respeito de determinada matéria é pela via direta, ou seja, por sua própria voz, por seu próprio voto. A entrega da manifestação de tal vontade a um representante naturalmente a sujeita a distorções. O Executivo ou o Legislativo precisará interpretar a vontade prevalecente na sociedade a respeito de determinada matéria. Tal interpretação sujeita-se ao erro e às limitações do próprio sujeito que interpreta. A vontade da maioria pode divergir das convicções dos seus representantes sobre determinando assunto. Pode conflitar, ainda, com os interesses dos partidos ou com os interesses pessoais dos parlamentares. Todos esses aspectos podem ensejar desvios representativos.

O sistema eleitoral também dispõe de particularidades que demandam atenção. Os membros da Câmara dos Deputados são eleitos pelo sistema proporcional de listas abertas. Nesse sistema, a maior parte dos candidatos não se elege com base na votação individual que recebe, mas sim com base na votação computada pelos partidos. Quanto maior é a votação recebida por um partido, maior será o número de assentos que conquistará na Câmara dos Deputados. Dentro de cada partido, os assentos conquistados serão preenchidos pelos candidatos mais votados ${ }^{6}$.

6 No sistema proporcional de listas abertas, os votos válidos são aqueles conferidos à legenda partidária e ao candidato. $\mathrm{O}$ quociente eleitoral diz respeito ao índice de votos a ser obtido para a distribuição das vagas. É calculado pela divisão dos votos válidos pelo número de lugares a serem preenchidos no Legislativo. O quociente partidário refere-se ao número de vagas alcançado pelos partidos na casa leg-
Os partidos políticos, como é de conhecimento geral, não possuem definições ideológicas claras e formam coligações partidárias de ocasião, com o propósito de aumentar suas chances de sucesso nas eleições. Valem-se, ainda, do expediente de lançar a candidaturas de personalidades populares, como artistas, jogadores de futebol e/ou políticos polêmicos e extremistas, como forma de captar a atenção, de majorar artificialmente a votação recebida pela agremiação e, por consequência, aumentar o número de cadeiras conquistadas no parlamento ${ }^{7}$.

Em razão disso, a votação recebida por cada partido pode não espelhar a efetiva concordância dos eleitores com suas inclinações ideológicas e com seus projetos - quando esses efetivamente existem. Ao votar em um candidato, o voto do eleitor é computado em favor do partido, podendo, por conseguinte, beneficiar diversos outros candidatos que integram a sua lista e com os quais não tem qualquer afinidade ideológica. Nessas condições, torna-se difícil avaliar a representatividade e a responsividade dos parlamentares ${ }^{8}$.

O impacto do poder econômico sobre as eleições e sua interferência sobre o sistema representativo também merece ser considerado. As eleições, no Brasil, têm mobilizado importâncias cada vez maiores, e as perspectivas de sucesso são diretamente proporcionais aos valores gastos nas campanhas. Como o financiamento privado por pessoas jurídicas era admitido de forma ilimitada, a capacidade dos candidatos de levantarem recursos privados tinha um papel relevante nas eleições. Por consequência, aqueles que desejassem concorrer em eleições futuras precisavam manter relações positivas com empresários e grupos econômicos capazes de contribuir para suas campanhas. Nessas condições,

islativa. É calculado pela divisão do número de votos conferidos ao partido ou aos seus candidatos pelo quociente eleitoral.

7 MS 26.602, MS 26.603 e MS 26.604, voto do Min. Gilmar Mendes, DJ, 03 out. 2008; PEREIRA, Rodolfo Viana; GELAPE, Lucas de Oliveira. O anacronismo do sistema proporcional de lista aberta no Brasil. Revista de Informação Legislativa, n. 205, p. 261-279, jan./mar. 2015.

8 As pesquisas disponíveis indicam que poucos eleitores se lembram dos candidatos a deputados em que votaram, o que sugere que não acompanham a sua atuação. Os parlamentares, por sua vez, atribuem o apoio recebido nas campanhas à conexão com a vida política local. De modo geral, consideram importante visitar habitualmente os municípios em que tiveram votação expressiva, obter recursos do orçamento para tais áreas e encaminhar pleitos de prefeitos e de lideranças locais. V. NICOLAU, Jairo. O sistema eleitoral de listas abertas no Brasil. Dados: Revista de Ciências Sociais. Rio de Janeiro, v. 49, n. 4, p. 689-720, 2006 a. 
contrariar determinados interesses empresariais poderia se tornar extremamente oneroso e implicar na inviabilidade de candidaturas futuras?.

Outro fator que interfere sobre a representatividade do Legislativo, em nosso sistema, é o número de cadeiras titularizado por cada estado em cada uma das casas do Congresso. No Senado, o número de representantes é fixo por determinação constitucional, correspondendo a três representantes por ente da federação ${ }^{10}$. Por consequência, os estados que detêm maioria nessa casa não necessariamente correspondem à maioria da população. Na Câmara, embora o número de membros deva guardar proporcionalidade com a população de cada estado, a Constituição prevê o limite mínimo de 8 (oito) e o limite máximo de 70 (setenta) deputados por ente. Disso resulta que os estados mais populosos possuem representação proporcionalmente menor do que os menos populosos, aspecto que também pode impactar sobre o caráter majoritário das deliberações do Congresso ${ }^{11}$.

Vale notar, ainda, que a Constituição de 1988 é extremamente analítica, tendo constitucionalizado um rol amplíssimo de matérias que vão desde o regime jurídico aplicável aos servidores públicos e às relações trabalhistas (regime este obstativo de reformas relevantes em momentos de crise) até normas eleitorais e regras sobre foro especial por prerrogativa de função (que favorecem a manutenção do status quo). A alteração de tais normas, por meio de emendas constitucionais, exige super maiorias correspondentes a 3/5 (três quintos) dos membros de cada casa do Congresso, o que significa, na prática,

9 ADI 4650, Rel. Min. Luiz Fux, Pleno, DJe, 24 fev. 2016.

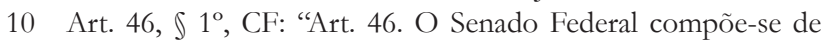
representantes dos Estados e do Distrito Federal, eleitos segundo o princípio majoritário. $\int 1^{\circ}$ - Cada Estado e o Distrito Federal elegerão três Senadores, com mandato de oito anos". BRASIL. Constituição (1988). Constituição da República Federativa do Brasil de 1988. Disponível em: < http://www.planalto.gov.br/ccivil_03/constituicao/constituicaocompilado.htm>. Acesso em: 24 mar. 2016.

11 Art. 45, $\iint 1^{\circ}$ e $2^{\circ}, \mathrm{CF}$, dispõe: "Art. 45. A Câmara dos Deputados compõe-se de representantes do povo, eleitos, pelo sistema proporcional, em cada Estado, em cada Território e no Distrito Federal. $\int 1^{\circ}-\mathrm{O}$ número total de Deputados, bem como a representação por Estado e pelo Distrito Federal, será estabelecido por lei complementar, proporcionalmente à população, procedendo-se aos ajustes necessários, no ano anterior às eleições, para que nenhuma daquelas unidades da Federação tenha menos de oito ou mais de setenta Deputados. \ $2^{\circ}$ - Cada Território elegerá quatro Deputados". BRASIL. Constituição (1988). Constituição da República Federativa do Brasil de 1988. Disponível em: <http://www.planalto.gov.br/ ccivil_03/constituicao/constituicaocompilado.htm>. Acesso em: 24 mar. 2016. a possibilidade de bloqueio das pertinentes deliberações por parlamentares que representem uma minoria ${ }^{12}$.

Também no que respeita ao processo legislativo, registram-se, ainda, como medidas aptas a empoderar a minoria no Congresso: a derrubada de vetos presidenciais a projetos aprovados pelo Legislativo, porque dependente de quorum qualificado equivalente à maioria absoluta de senadores e deputados ${ }^{13}$; bem como o procedimento especial, abreviado e célere, de aprovação de medidas provisórias, que exclui a submissão do projeto de lei às comissões temáticas, reduz o debate em torno da norma e enseja o trancamento da pauta do Congresso Nacional ${ }^{14}$. Até bem pouco tempo, admitia-se a inclusão de emendas parlamentares aos projetos de leis de conversão de medidas provisórias, sem que tais emendas guardassem qualquer relação com o tema objeto do projeto. Grupos de interesses passaram a se valer desse expediente para obter, junto ao Congresso, a aprovação inadvertida, açodada e desprovida de debate, de normas a respeito de temas de profunda relevância para o país ${ }^{15}$.

Basta lembrar que o regime diferenciado de contratação pública (RDC) ${ }^{16}$, que flexibilizou as normas so-

12 Art. 60: "A Constituição poderá ser emendada mediante proposta: I - de um terço, no mínimo, dos membros da Câmara dos Deputados ou do Senado Federal; II - do Presidente da República; III - de mais da metade das Assembleias Legislativas das unidades da Federação, manifestando-se, cada uma delas, pela maioria relativa de seus membros. [...]. $\ 2^{\circ}-$ A proposta será discutida e votada em cada Casa do Congresso Nacional, em dois turnos, considerandose aprovada se obtiver, em ambos, três quintos dos votos dos respectivos membros". BRASIL. Constituição (1988). Constituição da República Federativa do Brasil de 1988. Disponível em: <http:// www.planalto.gov.br/ccivil_03/constituicao/constituicaocompilado.htm>. Acesso em: 24 mar. 2016.

13 Art. 66, \ $4^{\circ}, \mathrm{CF}$ : “O veto será apreciado em sessão conjunta, dentro de trinta dias a contar de seu recebimento, só podendo ser rejeitado pelo voto da maioria absoluta dos Deputados e Senadores, em escrutínio secreto". BRASIL. Constituição (1988). Constituição da República Federativa do Brasil de 1988. Disponível em: <http:// www.planalto.gov.br/ccivil_03/constituicao/constituicaocompilado.htm>. Acesso em: 24 mar. 2016.

14 Art. 62, \$6 $6^{\circ}, \mathrm{CF}$ : "Se a medida provisória não for apreciada em até quarenta e cinco dias contados de sua publicação, entrará em regime de urgência, subseqüentemente, em cada uma das Casas do Congresso Nacional, ficando sobrestadas, até que se ultime a votação, todas as demais deliberações legislativas da Casa em que estiver tramitando". BRASIL. Constituição (1988). Constituição da República Federativa do Brasil de 1988. Disponível em: <http:// www.planalto.gov.br/ccivil_03/constituicao/constituicaocompilado.htm >. Acesso em: 24 mar. 2016.

15 ADI 5127, Rel. p/ o acórdão Min. Edson Fachin, Pleno, DJe, 11 maio 2016.

16 O Regime Diferenciado de Contratação Pública (RDC) foi 
bre licitações para contratações públicas ${ }^{17}$, com tantas potenciais repercussões sobre o bom uso dos recursos da coletividade, foi aprovado por meio de emenda parlamentar a projeto de lei de conversão de medida provisória, sem qualquer relação com o tema objeto da emenda ${ }^{18}$. Vale o registro, ainda, de que, posteriormente, o mesmo regime, originalmente justificado pela necessidade de viabilizar contratações mais céleres para cumprir prazos de estruturação para a Copa das Confederações de Futebol de 2013, para a Copa do Mundo de 2014 e para as Olimpíadas, teve seu objeto ampliado pelo mesmo mecanismo - emenda parlamentar sem pertinência temática - para hipóteses sem qualquer relação com os referidos eventos, tais como a contratação de obras do Programa de Aceleração da Economia e obras e serviços do Sistema Único de Saúde ${ }^{19}$.

As normas constantes dos regimentos internos do Senado e da Câmara dos Deputados possibilitam, por outro lado, que se estabeleçam múltiplas exigências durante a tramitação dos projetos de lei, de forma a postergar a sua apreciação. Exemplo desse tipo de artifício é a submissão de diplomas que contrariem interesses de minorias poderosas a diversas comissões temáticas, de forma a evitar a sua efetiva apreciação pela maioria da casa legislativa. Por esse mecanismo, o projeto pode acabar arquivado sem que sequer venha a ser efetiva-

criado pela Lei 12.462/2011, por meio de emenda sem pertinência temática com a Medida Provisória (MP) 527/2011. As considerações tecidas neste artigo ao seu respeito baseiam-se em pesquisa desenvolvida por Mateus Capatti, no âmbito do Núcleo de Produção de Monografias de Bacharelado da graduação em Direito da UniCEUB. 17 GUIMARÃES, José. Parecer apresentado em Plenário pelo Relator Designado para manifestar-se pela Comissão incumbida da apreciação da matéria: Medida Provisória no 527, de 2011. Disponível em: <http:// www.camara.gov.br/proposicoesWeb/prop_mostrarintegra?codte or $=890021 \&$ filename $=$ Tramitacao $-\mathrm{MPV}+527 / 2011>$. Acesso em: 23 mar. 2016.

18 A MP 527/2011 tinha por objeto a criação da Secretaria de Aviação Civil, a autorização da contratação de controladores de tráfego aéreo e a criação do Fundo Nacional de Aviação Civil. Não versava, portanto, sobre regime diferenciado de contratações públicas.

19 V. art. $1^{\circ}$, inc. IV, da Lei $12.462 / 2011$, com redação conferida pela Lei 12.688/2012, oriunda de emenda parlamentar que não aguardava pertinência temática com a MP 559/2012; e inc. V do mesmo dispositivo, com redação dada pela Lei 12.745/2012, produto de emenda parlamentar sem pertinência temática com a MP 580/2012. BRASIL. Lei $n^{\circ} 12.688$, de 18 de julbo de 2012. Disponível em: <http://www.planalto.gov.br/ccivil_03/_ato2011-2014/2012/ lei/112688.htm>. BRASIL. Lei no 12.745, de 19 de dezembro de 2012. Disponível em: <http://www.planalto.gov.br/ccivil_03/_ato20112014/2012/Lei/L12745.htm>. Acessos em: 24 mar. 2016. mente votado ${ }^{20}$.

Os eleitores, por sua vez, sabem muito pouco sobre o que efetivamente se passa no âmbito do poder público. É muito baixo o nível de informação de que se dispõe a tal respeito. Para se manterem adequadamente informados sobre os assuntos relevantes para o país, os cidadãos dependem de corpos intermediários dentre os quais destaca-se a imprensa. Entretanto, como se demonstrará mais adiante neste trabalho, a imprensa não é neutra, nem quanto à escolha dos assuntos a serem reportados, nem quanto à versão dos fatos que será disponibilizada.

Parte relevante dos fatos que ocorrem na seara pública não chega ao conhecimento dos cidadãos. A parte que chega a seu conhecimento não necessariamente compõe um enredo fiel aos eventos como efetivamente ocorridos. E, de todo modo, a interpretação e a avaliação crítica dos informes pressupõem disponibilidade de tempo, interesse e uma formação mínima por parte da população. Sem acesso a bons níveis de informação, de educação, e sem juízo crítico a seu respeito, é muito difícil que o eleitor efetivamente participe do debate público e exerça um controle sobre como agem os seus representantes. Também por isso, nem todas as atitudes e votos dos parlamentares se refletirão nas urnas, em futuras eleições.

20 De acordo com o Regimento Interno da Câmara dos Deputados: "Art. 140. Quando qualquer Comissão pretender que outra se manifeste sobre determinada matéria, apresentará requerimento escrito nesse sentido ao Presidente da Câmara, com a indicação precisa da questão sobre a qual deseja o pronunciamento [...].” Já o Regimento Interno do Senado prevê: "Art. 279. A discussão, salvo nos projetos em regime de urgência e o disposto no art. 349, poderá ser adiada, mediante deliberação do Plenário, a requerimento de qualquer Senador ou comissão, para os seguintes fins: I - audiência de comissão que sobre ela não se tenha manifestado; II - reexame por uma ou mais comissões por motivo justificado". Segundo definição da própria Câmara dos Deputados, as comissões permanentes que a integram: "São órgãos técnicos criados pelo Regimento Interno da Casa e constituídos de deputados(as), com a finalidade de discutir e votar as propostas de leis que são apresentadas à Câmara. Com relação a determinadas proposições ou projetos, essas comissões se manifestam emitindo opinião técnica sobre o assunto, por meio de pareceres, antes de o assunto ser levado ao Plenário; com relação a outras proposições elas decidem, aprovando-as ou rejeitando-as, sem a necessidade de submissão ao Plenário. A composição parlamentar desses órgãos técnicos é renovada a cada ano ou sessão legislativa". Disponível em: <http://www2.camara.leg.br/atividadelegislativa/comissoes>. Acesso em: 01 jun. 2013. 


\section{A INSTÂNCIA CONTRAMAJORITÁRIA PODE SER REPRESENTATIVA? CASOS EM QUE A JURISDIÇÃO CONSTITUCIONAL DEU VAZÃO À VONTADE POPULAR}

Segundo a doutrina constitucional, dois aspectos centrais justificam a invalidação de atos dos representantes eleitos pela jurisdição constitucional, sem que se possa falar em violação ao princípio democrático: i) a proteção dos direitos fundamentais e ii) a garantia do adequado funcionamento do próprio processo democrático ${ }^{21}$. De acordo com essa concepção, os direitos fundamentais teriam sido retirados pelo constituinte originário do alcance da deliberação majoritária porque representam aspectos inerentes à dignidade dos indivíduos, sem os quais não faria sentido viver em comunidade. A garantia de tais direitos seria, por isso, pressuposto de validade do próprio exercício do poder político.

A atuação das cortes constitucionais para assegurar o respeito ao adequado funcionamento do processo democrático, por sua vez, teria o propósito de assegurar a legitimidade das deliberações da maioria, evitando que essas sejam distorcidas. A título ilustrativo, medidas do Congresso que impliquem o cerceamento do exercício do direito de voto ou a limitação da circulação de informação sobre os candidatos violarão o princípio democrático mesmo que sejam produzidas com o alegado aval da maioria (porque podem mascará-la) e, por consequência, devem ter a inconstitucionalidade reconhecida $^{22}$. Essas são as razões tradicionalmente utilizadas

21 A discussão sobre a legitimidade democrática da jurisdição constitucional é abordada nos limites da necessidade desse trabalho e sem pretensão exaustiva. Sobre o tema, v., entre outros: DWORKIN, Ronald. Uma questão de princípio. Trad.: Luís Carlos Borges. São Paulo: M. Fontes, 2000; e DWORKIN, Ronald. Levando os direitos a sério. Trad.: Jefferson Luiz Camargo. São Paulo: M. Fontes, 2003; ELY, John Hart. Democracy and distrust. A theory of judicial review. Cambridge, London: Harvard University Press, 1980; ELSTER, John. Ulysses and the syrens. Cambridge: Cambridge University Press, 1979; e ELSTER, John. Ulysses unbound - Studies in rationality, precomitments and constraints. Cambridge: Cambridge University Press, 2000; ALEXY, Robert. Constitucionalismo Discursivo. Trad.: Luis Afonso Heck. Porto Alegre: Livraria do Advogado, 2007; ACKERMAN, Bruce. We the people - Transformations. Cambridge: Harvard University Press, 1998; BINENBOJM, Gustavo. A nova jurisdição constitucional brasileira: legitimidade democrática e instrumentos de realização. Rio de Janeiro: Renovar, 2001.

22 É válido destacar, ademais, que a ideia de democracia, ou de governo pelo povo, não se esgota na observância do princípio majoritário. É preciso que a igualdade de participação e de oportunidades seja minimamente assegurada, sem o que não há que se falar adequadamente em autogoverno. V. DWORKIN, Ronald. Freedom's Law: The moral reading of the American constitution. Cambridge: para justificar o poder judicial de invalidar atos do Executivo e do Legislativo, a despeito de serem integrados por membros eleitos pelo voto popular ${ }^{23}$.

Pode acontecer, ainda, de o Tribunal, ao efetuar o controle da constitucionalidade das normas, dar vazão justamente a pleitos da maioria que não foram acolhidos nas instâncias majoritárias. Não é correto associar o respeito à decisão produzida pelo Legislativo ou pelo Executivo à observância princípio democrático. Ao contrário, uma observação atenta permite constatar que decisões judiciais convergentes com o entendimento prevalecente na comunidade, proferidas em sede de controle de constitucionalidade, são mais comuns do que se imagina. Apresentam-se, a seguir, alguns casos que confirmam essa assertiva ${ }^{24}$.

i) Foro especial por prerrogativa de função

O primeiro desses casos diz respeito ao foro especial por prerrogativa de função. De acordo com o art. 102, I, (a) e (b), da Constituição, compete ao Supremo Tribunal Federal processar e julgar - originariamente - nas infrações penais comuns e nos crimes de responsabilidade as mais altas autoridades da República ${ }^{25}$. Segundo entendimento da jurisprudência centenária do $\mathrm{STF}^{26}$, con-

Harvard University Press, 1996. p. 16-17.

23 Tais razões justificam apenas parte da atuação do Supremo Tribunal Federal, que, em diversas situações, aprecia a constitucionalidade de atos em face de normas formalmente constitucionais, que não correspondem a direitos fundamentais ou se relacionam com o respeito ao processo democrático. A legitimação do STF para atuar com tamanha amplitude deriva, no caso brasileiro, de normas constitucionais expressas, que podem, todavia, ser problematizadas. DWORKIN, Ronald. Freedom's Law: The moral reading of the American constitution. Cambridge: Harvard University Press, 1996. p. 16-17.

Tais razões justificam apenas parte da atuação do Supremo Tribunal Federal. Em diversas situações, o Tribunal aprecia a constitucionalidade de atos em face de normas apenas formalmente constitucionais, que não interferem sobre direitos fundamentais ou se relacionam com o funcionamento do processo democrático. A legitimação do STF para atuar com tamanha amplitude deriva, no caso brasileiro, de normas constitucionais expressas.

24 BARROSO, Luís Roberto. Constituição, democracia e supremacia judicial: direito e política no Brasil contemporâneo. p. 33. Disponível em: <http://www.luisrobertobarroso.com.br/pt/noticias/constituicao_democracia_e_supremacia_judicial_11032010.pdf $>$. Acesso em: 2 jul. 2012; MELLO, Patrícia Perrone Campos. Nos bastidores do Supremo Tribunal Federal. Rio de Janeiro: Forense, 2015. p. 293 e ss.

25 Cf. art. 102, I, (a) e (b), CF. BRASIL. Constituição (1988). Constituição da República Federativa do Brasil de 1988. Disponível em: $<$ http://www.planalto.gov.br/ccivil_03/constituicao/constituicaocompilado.htm>. Acesso em: 24 mar. 2016.

26 A primeira decisão de que se tem notícia em tal sentido dataria de 25 de janeiro de 1842. Inquérito n. 687-4, STF, Pleno, Rel. Min. 
solidada em súmula simples e aplicada por pelo menos dez anos durante a vigência da Constituição de 1988, tal prerrogativa de foro se estenderia, ainda, aos ex-mandatários e aos ex-ocupantes de cargos públicos, a despeito de a Constituição não ter sido expressa no ponto, porque a independência da autoridade no exercício do cargo deveria ser preservada pela certeza de que, mesmo quando não estivesse mais no poder, ser-lhe-ia assegurado um julgamento justo e neutro, diretamente pela mais alta corte do país e não por qualquer outra instância ${ }^{27}$.

Ocorre que a prerrogativa de foro era compreendida pela população como sinônimo de impunidade porque, na prática, pouquíssimas são as ações penais efetivamente processadas pelo STF e mais raras ainda eram as condenações. De modo geral, a maior parte dos casos restava prescrita sem que uma resposta adequada fosse dada pelo Tribunal, situação que causava desgastes para sua credibilidade. Duas eram as explicações usualmente utilizadas para esse tipo de desfecho nos casos de foro especial. Afirmava-se que o julgamento de tais ações criminais demandavam do ministro relator uma atuação de juiz de primeiro grau, coletando e apreciando provas e ouvindo testemunhas, atuação para a qual o STF não estaria aparelhado, por se tratar de tribunal superior. E alegava-se que essa particularidade, somada à enorme sobrecarga de processos enfrentada pela Corte, acabava prejudicando o julgamento dos referidos casos.

Suprimir o foro especial das autoridades que se encontravam no curso do mandato ou na posse dos cargos de alto escalão demandaria a aprovação de uma emenda constitucional, já que a literalidade da Constituição não deixava dúvidas quanto à competência do STF para julgá-las, no que respeita à prática de crimes comuns e/ou de responsabilidade. Entretanto, a prerrogativa de foro de ex-mandatários e de ex-ocupantes de cargos públicos decorria de mera construção jurisprudencial. Poderia, portanto, ser revertida pela própria Corte.

Assim, em 1999, o STF decidiu superar sua antiga súmula para afirmar que a prerrogativa de foro se limitava àquelas autoridades que estivessem cumprindo o mandato ou que estivessem na posse do cargo. Uma vez findo o mandato ou exonerada do cargo, o STF declinaria da sua

Sydney Sanches, j. 25 ago. 1999, DJ 9 nov. 2001, voto do Ministro Sepúlveda Pertence.

27 Súmula 394, STF: "Cometido o crime durante o exercício funcional, prevalece a competência especial por prerrogativa de função, ainda que o inquérito ou a ação penal sejam iniciados após a cessação daquele exercício". competência e encaminharia o feito ao juiz natural para prosseguimento. Justificou-se a nova decisão com base no argumento literal de que a competência para julgar ex-ocupantes não estava expressa na letra da Constituição (diferentemente do que ocorria nas constituições anteriores). Alegou-se, ainda, que tal prerrogativa de foro voltava-se a proteger o exercício do mandato ou do cargo, não seu ex-titular, e que, por se tratar de exceção à regra geral, deveria receber interpretação restritiva.

A decisão não foi bem recebida pelos parlamentares, que se beneficiavam com a prerrogativa de foro. Por isso, em resposta a ela, o Congresso aprovou a Lei $n^{\circ}$ 10.628/02, que alterava o art. 82 do Código Penal para estabelecer que a competência especial por prerrogativa de função, relativa a atos administrativos do agente, prevaleceria ainda que o inquérito ou a ação judicial fossem iniciados após a cessação do exercício da função pública. Entretanto, a nova lei foi declarada inconstitucional em sede concentrada pelo STF, tendo-se reiterado, durante o julgamento, que a experiência mostrava que o STF não era um tribunal vocacionado para o exercício dessa competência ${ }^{28}$. Houve, igualmente, menção ao fato de que, de modo geral, os casos levados ao Tribunal restavam impunes ${ }^{29}$. Um ano mais tarde, alguns membros do Congresso voltariam a insistir na tentativa de reverter tal entendimento, desta vez, por meio de um projeto de emenda constitucional ${ }^{30}$.

O caso antes narrado é bem ilustrativo de como as instâncias majoritárias podem divergir do sentimento popular. De acordo com pesquisa contratada pela Associação dos Magistrados Brasileiros então, 79,8\% da população eram contra o foro especial ${ }^{31}{ }^{32}$. A despeito disso, o Congresso fez o que pode para mantê-lo na maior extensão possível. Curiosamente, coube ao Supremo Tribunal Federal, composto por juízes vitalícios e independentes, atender às expectativas da população. Em virtude disso, o foro especial por prerrogativa de

28 ADIs 2797 e 2860, Rel. Min. Sepúlveda Pertence, Pleno, DJ, 19 dez. 2006.

29 V. voto do Ministro Carlos Veloso nas ADINs n. 2797 e 2860. 30 ASSOCIAÇÃO DOS MAGISTRADOS BRASILEIROS. Juizes Contra a Corrupção. Disponível em: <http://www.amb.com.br/portal/ docs/noticias/estudo_corrupcao.pdf>. Acesso em: 18 jun. 2013.

31 OPINIÃO CONSULTORIA. A imagem das instituições públicas brasileiras. Brasília, set. 2007. p. 13. Disponível em: <http://www. amb.com.br/docs/pesquisa/imagem_instituicoes.pdf >. Acesso em: 18 jun. 2013.

32 Embora as pesquisas de opinião se sujeitem a alguma margem de erro, elas são um critério objetivo para aferir a opinião popular sobre determinado tema. 
função para ex-ocupantes de cargos e para ex-detentores de mandato deixou de existir.

Persiste, contudo, o foro para ocupantes e detentores atuais de mandatos (juntamente os mesmos problemas já narrados), já que a sua supressão nessa hipótese dependia da atuação dos parlamentares, por meio de emenda constitucional, o que, como era de se imaginar, até o momento, ainda não aconteceu. A matéria continua na ordem do dia. E a necessidade de alterar o foro especial vem sendo reiteradamente apontada por membros da Corte ${ }^{33}$.

\section{ii) Fidelidade partidária}

Um segundo caso em que o STF claramente deu vazão ao anseio popular foi aquele em que afirmou o dever de fidelidade partidária dos parlamentares eleitos pelo sistema proporcional de listas abertas. Como já mencionado acima, os candidatos, no referido sistema, geralmente se elegem com base na votação obtida pelo partido e não com base na votação individual do candidato. A despeito disso, durante muito tempo, o STF entendeu que o parlamentar eleito por intermédio de determinado partido não estava obrigado a permanecer na agremiação, podendo deixá-la a qualquer tempo e ainda assim manter o seu mandato. $\mathrm{O}$ entendimento tinha por base o fato de que o dispositivo constitucional que previa a perda do mandato por infidelidade partidária, na vigência da Constituição anterior, fora revogado pela Emenda Constitucional 25/1985 e não voltou a ser inserido na Constituição de 1988. Como a última trazia um rol das causas de perda de mandato e tendo em vista que tais causas constituem situações excepcionais, conferiu-se a elas interpretação restritiva ${ }^{34}$.

Em consequência, os deputados ficaram livres para se elegerem por um partido e, depois, mudarem de partido de acordo com interesses de ocasião. O troca-troca de agremiações tornou-se uma prática comum, que não desagradava aos partidos maiores. Com bancadas mais amplas e maior poder de barganha no Legislativo, esses partidos conseguiam atrair parlamentares infiéis de partidos menores e, assim, majorar seu poder no Congresso. Entretanto, tal prática constituía um grave problema para as agremiações menores. Embora o partido fosse

33 MEGALE, Bela. Ministro Luís Roberto Barroso quer o fim do foro privilegiado. Folha de São Paulo, 23 maio 2016. Disponível em: <http://www1.folha.uol.com.br/poder/2016/05/1774158ministro-do-stf-luis-roberto-barroso-quer-fim-do-foro-privilegiado. shtml >. Acesso em: 26 nov. 2016.

34 MS 20.927, Rel. Min. Moreira Alves, Pleno, DJ, 15 abr. 1994. determinante para a eleição de um deputado, corria o risco de perder todos os deputados que elegeu e, portanto, de não mais poder exercitar seu direito ao funcionamento parlamentar, a despeito de ter tido um razoável desempenho eleitoral. Tal expediente poderia, por sua vez, anular o direito de oposição e de representação das minorias e indiscutivelmente distorcia o processo democrático representativo.

Quase vinte anos haviam se passado, desde o julgamento do leading case em que o Supremo Tribunal Federal havia apreciado a matéria, quando este finalmente decidiu reexaminá-la. Nessa ocasião, observou que, na legislatura em curso, o percentual de deputados eleitos por votação individual era de aproximadamente $6 \%$ (seis por cento) apenas, de modo que ficava evidente que a conquista do mandato era resultante, ao menos, do somatório do desempenho eleitoral dos candidatos e dos partidos. Por essa razão e em respeito ao caráter representativo do mandato, uma vez eleito, o deputado não poderia simplesmente desligar-se da agremiação, como se fosse ela um mero instrumento de acesso ao poder. A troca de partido só poderia ocorrer caso demonstrasse estar sofrendo perseguição dentro da agremiação ou caso comprovasse ter havido alteração ideológica relevante. Excepcionadas tais circunstâncias, o desligamento do partido implicaria na quebra do dever de fidelidade partidária e, consequentemente, na perda do mandato parlamentar em favor do partido ${ }^{35}$.

A decisão seguramente não atendida aos interesses dos partidos que tinham maioria na Câmara dos Deputados e que poderiam ter corrigido tal distorção pela via legislativa. Não havia interesse em fazê-lo porque ela se prestava bem à preservação de seu poder na Câmara. Todavia, de acordo com pesquisa realizada pelo Instituto Brasileiro de Opinião Pública e Estatística - IBOPE, contratada pela Confederação Nacional das Indústrias CNI, $52 \%$ da população eram favoráveis à implementação do dever de fidelidade partidária contra $37 \%$, que se manifestaram contra a medida. Mais uma vez, portanto, coube ao STF dar voz aos anseios da maioria.

iii) Financiamento privado de campanha eleitoral

No terceiro caso selecionado, o Supremo Tribunal Federal apreciou a constitucionalidade do sistema privado de financiamento das campanhas eleitorais. $\mathrm{Na}$ ação, proposta

35 MS 26.602, Rel. Min. Eros Grau, Pleno, DJe, 17 out. 2008; MS 26.603, Rel. Min. Celso de Mello, Pleno, DJe, 19 dez. 2008; e MS 26.604, Rel. Min. Cármen Lúcia, Pleno, DJe, 3 out. 2008 
pelo Conselho Federal da Ordem dos Advogados, pleiteava-se: i) a declaração da inconstitucionalidade da doação por pessoas jurídicas a campanhas eleitorais ou a partidos políticos; ii) a limitação das doações de pessoas físicas e do uso de recursos próprios pelos candidatos para os mesmos fins, a fim de assegurar a igualdade nas eleições ${ }^{36}$.

De acordo com o relator do feito, Ministro Luiz Fux, em apenas dez anos, havia-se testemunhado um crescimento exponencial do custo das campanhas eleitorais: dos 798 milhões de reais, gastos em 2002, para mais de 4,5 bilhões de reais, em 2012, um aumento de 471\% em dez anos. Ainda segundo o relator, estima-se que $0,89 \%$ do produto interno bruto do Brasil era gasto no financiamento de campanhas eleitorais, quando, nos Estados Unidos da América, em que as campanhas são conhecidas por seus números expressivos, tal percentual alcançaria apenas 0,38\% do PIB. Este e outros argumentos levaram o ministro a reconhecer a "crescente influência do poder econômico sobre o processo político" 37 .

Constatou-se, ainda, que, quanto maior a capacidade de angariar recursos, maiores as chances de eleição dos políticos. Os candidatos eleitos não eram aqueles que apresentavam as melhores propostas, mas aqueles com financiamento mais robusto. Não representavam os cidadãos que os elegeram, mas os grupos econômicos que os financiaram. Tais grupos, por sua vez, se dispunham a verter tamanhas importâncias para campanhas eleitorais porque esperavam colher benefícios com a eleição dos candidatos apoiados. O quadro, tal como delineado, se mostrava incompatível com o princípio da igualdade de chances nas eleições e com o regime democrático.

Com base nesses argumentos, o STF julgou a ação parcialmente procedente para assentar a inconstitucionalidade do financiamento privado de campanhas por pessoas jurídicas tal como regulado na legislação em vigor, deixando aberta, contudo, a possibilidade de o po-

36 ADI 4650, Rel. Min. Luiz Fux, Pleno, DJe, 24 fev. 2016.

37 Confira-se trecho do acórdão: "Na mesma Audiência, o expositor e professor Geraldo Tadeu demonstrou que o gasto per capita nas campanhas eleitorais no Brasil é bastante superior aos da França, da Alemanha e do Reino Unido. No Brasil, essa cifra atinge o montante de $\$ 10,93$, enquanto que na França é de $\$ 0,45$, no Reino Unido, de $\$ 0,77$, e na Alemanha chega a 2,21. Quando comparado proporcionalmente ao PIB, o Brasil também se encontra no topo do ranking dos países que mais gastam com campanhas eleitorais: $0,89 \%$ de toda a riqueza gerada no país se presta a financiar candidaturas a cargos representativos. Aqui, ultrapassamos, inclusive, os Estados Unidos, em que apenas $0,38 \%$ do PIB vai para as campanhas eleitorais". Não fica claro, no trecho, o período a que os percentuais de $0,89 \%$ e $0,38 \%$ do PIB de cada país se referem. der Legislativo dispor sobre o tema em outras bases ${ }^{38}$.

Merece menção, contudo, o fato de que, quando o julgamento ainda estava em curso no STF, a Câmara dos Deputados levou à deliberação uma emenda constitucional que autorizava expressamente o financiamento privado de campanha por pessoa jurídica. A manobra tinha o propósito evidente de neutralizar o entendimento que seria proferido pelo Tribunal. Esse primeiro projeto de emenda foi rejeitado na Câmara, mas, um dia mais tarde, uma nova emenda sobre o tema foi aprovada, sob forte pressão de alguns grupos de parlamentares, permitindo a doação de pessoas jurídicas privadas a partidos ${ }^{39}$. Em seguida, o projeto foi encaminhado ao Senado para votação e pende de apreciação.

Ao que tudo indica, também nesse caso as instâncias majoritárias se afastaram da vontade popular e coube ao Supremo dar-lhe voz. De acordo com pesquisa divulgada pelo Datafolha, $74 \%$ da população eram contra o financiamento de campanha por empresas privadas e $79 \%$ estavam convictos de que esse tipo de financiamento estimulava a corrupção ${ }^{40}$.

38 Constou da ementa do julgado: "Ausência de modelo constitucional cerrado de financiamento de campanhas. Constituiçãomoldura. Normas fundamentais limitadoras da discricionariedade legislativa. Pronunciamento do Supremo Tribunal Federal que não encerra o debate constitucional em sentido amplo. Diálogos institucionais. Última palavra provisória. Mérito. Doação por pessoas jurídicas. Inconstitucionalidade dos limites previstos na legislação ( $2 \%$ do faturamento bruto no ano anterior à eleição). Violação aos princípios democráticos e da igualdade política. Captura do processo político pelo poder econômico".

39 Proposta de Emenda à Constituição no 182/2007: “Art. 17. [...]. \$5 $55^{\circ}$ É permitido aos partidos políticos receber doações de recursos financeiros ou de bens estimáveis em dinheiro de pessoas físicas ou jurídicas. $\$ 6^{\circ}$ É permitido aos candidatos receber doações de recursos financeiros ou de bens estimáveis em dinheiro de pessoas físicas. $\$ 7^{\circ}$ Os limites máximos de arrecadação e gastos de recursos para cada cargo eletivo serão definidos em lei”. A aprovação do projeto na Câmara dos Deputados levou alguns de seus membros a impetrar o MS 33.630, perante o STF, distribuído à relatoria da Ministra Rosa Weber, alegando violação ao art. $60, \$ 5^{\circ}$, CF. Entretanto, a liminar foi indeferida. O referido dispositivo constitucional estabelece: " $\int 5^{\circ}$ A matéria constante de proposta de emenda rejeitada ou havida por prejudicada não pode ser objeto de nova proposta na mesma sessão legislativa". PASSARINHO, Natália. Câmara aprova por na Constituição doação de empresas a partidos. G1. Política. 25 maio 2015. Disponível em: <http://g1.globo.com/politica/ noticia/2015/05/camara-aprova-incluir-na-constituicao-doacao-de-empresas-partidos-politicos.html>. Acesso em: 6 maio 2015.

40 SOUZA, André. Datafolha: Três em cada quatro brasileiros são contra o financiamento de campanha por empresas privadas. O Globo, Rio de Janeiro, 6 jul. 2015. Disponível em: <http:// oglobo.globo.com/brasil/datafolha-tres-em-cada-quatro-brasileiros-sao-contra-financiamento-de-campanha-por-empresas-privadas-16672767>. Acesso em: 5 ago. 2015. Por outro lado, de acordo com pesquisa realizada pelo Instituto Sensus, $75,2 \%$ da população é 
4. CASOS EM QUe a JURISDição CONSTITUCIONAL SE CURVOU À VONTADE POPULAR

Há casos, ainda, em que se constatam fortes indícios de que a decisão proferida pelo Supremo Tribunal Federal teria sido outra, não fosse a vigilância e a pressão exercida pelo público e pela imprensa. Os dois casos selecionados para ilustrar essa assertiva dizem respeito a um tema que encontrou considerável resistência no poder Judiciário: a criação do Conselho Nacional de Justiça (CNJ), órgão destinado a realizar o controle administrativo, financeiro e disciplinar do Judiciário e de seus magistrados ${ }^{41}$.

i) A criação do Conselho Nacional de Justiça

O Conselho Nacional de Justiça foi criado pela Emenda Constitucional 45/2004, de reforma do Judiciário. Como é intuitivo, a magistratura não recebeu bem a inovação e a Associação dos Magistrados Brasileiros (AMB) propôs uma ação direta de inconstitucionalidade contra a norma, alegando que um órgão com composição hibrida destinado ao controle do Judiciário atentava contra a separação dos poderes, a independência dos juízes e as demais garantias da magistratura. Observou, ainda, que a Súmula 646 do STF estabelecia ser "inconstitucional a criação, por Constituição Estadual, de órgão de controle administrativo do Poder Judiciário do qual participem representantes de outros poderes ou entidades", situação semelhante àquela do CNJ.

A ação era particularmente delicada para o STF. À época em que a emenda de reforma encontrava-se em discussão, a Corte havia deliberado, em sessão administrativa, por uma maioria de sete ministros, manifestar-se contrariamente à criação de um órgão de controle integrado por agentes externos à magistratura. No entanto, o órgão foi aprovado pelo Congresso e amplamente acolhido pela imprensa, pela comunidade jurídica e pelo público em geral.

O Supremo integrava o poder Judiciário. Mesmo que não se submetesse, ele próprio, ao $\mathrm{CNJ}$, uma even-

contra o financiamento público exclusivo das campanhas eleitorais. V. MILITÃO, Eduardo. Maioria é contra financiamento público de campanha. Uol, Congresso em foco, 26 jun. 2007. Disponível em: $<$ http://congressoemfoco.uol.com.br/noticias/maioria-e-contrafinanciamento-publico-de-campanha/>. Acesso em: 5 ago. 2015. 41 Cf. art. 103-B, J 4 ${ }^{\circ}$, CF. BRASIL. Constituição (1988). Constituição da República Federativa do Brasil de 1988. Disponível em: $<$ http://www.planalto.gov.br/ccivil_03/constituicao/constituicaocompilado.htm>. Acesso em: 24 mar. 2016. tual decisão pela inconstitucionalidade do Conselho, no contexto, seria interpretada como corporativista e contrária aos avanços amplamente apoiados pela população. O caso colocava a legitimidade da Corte em xeque, e os debates travados entre os ministros, durante o julgamento, evidenciavam a divergência entre eles e a preocupação com a imagem do tribunal.

O Ministro Carlos Velloso, por exemplo, lembrava a todos que a posição contrária a um Conselho de natureza híbrida já fora firmada pela Corte e parecia cobrar coerência de alguns ministros que se manifestaram administrativamente neste sentido. Questionado, o Ministro Peluso observou que, em âmbito administrativo, fizera um juízo de conveniência sobre a composição que considerava mais adequada para o CNJ. Não lhe agradava a composição híbrida. Disso não resultava, contudo, que ela fosse necessariamente inconstitucional. Em um debate duro, insinuou-se que alguns ministros que estariam votando favoravelmente ao Conselho no caso em exame teriam tido sua posição original "convertida". Confira-se:

O SENHOR MINISTRO CARLOS VELLOSO - [...]. Na sessão administrativa convocada pela presidência, os Srs. Ministros MAURÍCIO CORRÊA, eu próprio, MARCO AURÉLIO, ELLEN GRACIE, GILMAR MENDES E CEZAR PELUSO votamos contra a inclusão no Conselho dos não magistrados, dos representantes do Senado, da Câmara, dos advogados e dos membros do Ministério Público. Seis Ministros, portanto. A estes votos acresceu, em parte, o voto do Ministro SEPÚlVEDA PERTENCE, que inadmitia os representantes do Senado e da Câmara, mas admitia os advogados e membros do Ministério Público. Sete ministros, portanto, não admitiam os representantes da Câmara e do Senado.

O SENHOR MINISTRO CEZAR PELUSO (RELATOR) - Vossa Excelência me permite? [...]. Quando dei minha opinião e, de certo modo, reafirmei hoje o meu ponto de vista, de que do ponto de vista da conveniência não me agrada realmente a participação nem de membros da advocacia, do Ministério Público, [do] cidadão, na estrutura do Conselho, não significava que a questão, do ponto de vista constitucional, não fosse outra.

O SENHOR MINISTRO CARLOS VELLOSO Perfeito, Ministro Cezar Peluso. É o que o Ministro Marco Aurélio diz, o juiz costuma evoluir.

O SENHOR MINISTRO NELSON JOBIM (PRESIDENTE) - Ninguém evoluiu, permanece a mesma posição.

O SENHOR MINISTRO CEZAR PELUSO (RELATOR) - Não. Ninguém evoluiu. Eu não evoluí nada. Eu continuo com a minha convicção. 
O SENHOR MINISTRO CARLOS VELLOSO Ou pode involuir também. Ou pode ser convertido. Saulo foi convertido. Felizmente, não caminhei na estrada de Damasco. ${ }^{42}$

Mas por quem os ministros teriam sido convertidos?

É possível que uma pista esteja na fundamentação dos votos proferidos por cada qual. De fato, nota-se, por seu exame, que diversos ministros aludiram, ao votar, à sua preocupação com as expectativas da sociedade a respeito do desfecho do caso. Nessa linha, o ministro Celso de Mello, manifestou-se pela constitucionalidade do órgão, aludindo ao "contexto histórico" do país e à "realidade política", que impunham a viabilização de um processo de "fiscalização social" dos atos não-jurisdicionais do poder Judiciário. ${ }^{43} \mathrm{O}$ ministro Eros Grau defendeu a criação do CNJ, observando que não se podia desconsiderar "o imaginário social” e suas "expectativas", sob pena de se promover enorme desgaste para o Tribunal. O ministro Nelson Jobim ressaltou que o Poder Judiciário tornara-se "uma preocupação nacional", em virtude de seu isolamento da sociedade, do seu corporativismo e da necessidade de melhorar o serviço prestado à população. E defendeu não apenas a validade do CNJ, mas igualmente a imprescindibilidade da sua composição híbrida para que o necessário controle disciplinar dos magistrados fosse verdadeiramente efetuado. ${ }^{44}$

42 ADIN 3367, Rel. Min. Cezar Peluso, Pleno, DJ, 17 mar. 2006, p. $142-144$.

43 ADIn 3367, p. 345-348.

44 ADIn 3367, p. 369-373. Confiram-se as contundentes palavras do Ministro Jobim: "Assisti, durante todos esses anos, ao debate real que se travava naqueles fóruns, exatamente o debate do espaço de cada uma dessas corporações [dos juízes, dos membros do Ministério Público, da OAB, das associações de advogados públicos, de advogados trabalhistas e de outros especialistas] no controle do Poder Judiciário. Muito pouco se debatia sobre celeridade, sobre eficiência, mas debatiam-se os conflitos entre os espaços de cada um. [...]. Tudo isso levou sempre a um desenho e a um modelo autônomo-corporativo de isolamento, na linguagem de Cappelleti, que era exatamente a absolutização da independência, isolando o Poder Judiciário do resto da organização estatal e da sociedade. [...]. Quando chegamos ao ano 2000, o Poder Judiciário passou a ser uma preocupação nacional; não era mais mera preocupação das categorias ou de juristas e acadêmicos. Por quê? Qual a razão de se debater muito sobre a necessidade de um órgão que tem duas funções? Uma, a principal, sob o meu ponto de vista, é exatamente a função da formulação de uma política nacional do Poder Judiciário. Isso é decorrente do isolamento absoluto dos 96 tribunais que compõem a estrutura brasileira de hoje - reduzidos, agora, a 93, tendo em vista a extinção dos tribunais de alçada. [...]. Creio que o aparte feito pelo Ministro Carlos Britto, na leitura de uma manifestação do Desembargador Vladimir Passos Freitas, mostra exatamente porque a sociedade brasileira, por meio do Congresso Nacional, resolveu instituir um órgão não só funda-
O ministro Marco Aurélio, por sua vez, manifestou-se pela inconstitucionalidade do CNJ, afirmando que se dava "uma esperança vã à sociedade brasileira" com essa providência, porque, em lugar de avaliar os problemas enfrentados pelo Judiciário, tratava-se o assunto como se fosse uma questão disciplinar. ${ }^{45}$

A preocupação de diversos membros da Corte em dar uma resposta à sociedade, as diversas alusões ao momento histórico, às expectativas da população, ao imaginário social, à superação de um modelo de isolamento social indicam que a pressão exercida pela comunidade sobre o Tribunal influenciou no desfecho do caso. Veja-se que a percepção do sentimento popular, no caso, tinha peso tal que levava seus membros a decidir contrariamente a interesses da própria magistratura, a despeito do histórico corporativista antes mencionado.

\section{ii) $\mathrm{O}$ poder disciplinar concorrente do Conselho}

Entretanto, as polêmicas em torno do $\mathrm{CNJ}$ haviam apenas começado. Em meados de 2011, o Conselho editou a Resolução 135/2011, que dispôs sobre o procedimento disciplinar aplicável aos magistrados, e previu sua competência concorrente (com os demais tribunais) para processar e julgar os juízes por faltas disciplinares ${ }^{46}$. Em resposta, uma nova ação direta de inconstitucionalidade foi proposta pela AMB, desta vez, contra a resolução. A Associação defendia, dessa vez, que a competência do CNJ era meramente subsidiária, de modo que este só poderia agir, caso se verificasse que os tribunais não estavam exercendo adequadamente seu poder disciplinar. O entendimento da AMB tinha por base a redação do art. $103-\mathrm{B}, \mathbb{S} 4^{\circ}$, incisos III e $\mathrm{V}^{47}$, bem como a alegada

mental de formulação de políticas, mas, também, um órgão supletivo da questão disciplinar. Como disse o próprio Desembargador, tendo em vista a sua experiência como, hoje, Presidente do Tribunal Regional Federal da $4^{\mathrm{a}}$ Região, é difícil se ver a correição horizontal, é muito fácil se ver a correição vertical; mas nem sempre. Por isso creio que a presença de dois membros do Conselho, oriundos do Congresso Nacional, um do Senado e outro da Câmara, mostra que estamos revertendo ou virando a curva do isolamento, porque se o Conselho fosse integrado apenas por magistrados, advogados e promotores, teríamos ainda a manutenção de um sistema corporativo e de isolamento. A presença de dois membros externos ao sistema judicial possibilita, fundamentalmente, inclusive, o constrangimento em relação às decisões que possam ser tomadas".

45 ADIn 3367 , p. 308 e ss.

46 O dispositivo tinha a seguinte redação: "Art. 12. Para os processos administrativos disciplinares e para a aplicação de quaisquer penalidades previstas em lei, é competente o Tribunal a que pertença ou esteja subordinado o Magistrado, sem prejuízo da atuação do Conselho Nacional de Justiça".

47 Art. 103-B: "§ $4^{\circ}$ Compete ao Conselho o controle da atuação 
necessidade de harmonizar as competências em questão com a autonomia administrativa dos tribunais. ${ }^{48}$

Ocorre, todavia, que o exercício concorrente da competência disciplinar por parte do Conselho Nacional de Justiça era aprovado pela população, que via a resistência da magistratura como uma atitude corporativista que favorecia a impunidade. A nova ação da AMB gerou, então, uma polarização das posições. A imprensa, por sua vez, contribuía para tal polarização. Exercia uma vigilância intensa e persistente sobre o Supremo Tribunal Federal, publicava reiteradas matérias sobre o assunto e afirmava que a liminar pleiteada pela AMB (pedindo para que a resolução do $\mathrm{CNJ}$ tivesse seus efeitos suspensos) ainda não havia sido apreciada pela Corte apenas porque esta se sentia pressionada pela opinião pública a decidir contra os interesses corporativos da associação. De fato, chegou-se a publicar:

Diante da forte reação da opinião pública e das críticas ao corporativismo no Judiciário, o Supremo Tribunal Federal (STF) desistiu de julgar ontem a ação que tira do Conselho Nacional de Justiça (CNJ) poderes para investigar e punir magistrados. A maioria dos ministros do STF tendia a aceitar a ação, movida pela Associação dos Magistrados Brasileiros (AMB), mas o presidente da Corte, Cezar Peluso, adiou sua apreciação. "O momento não é adequado. Vamos deixar até que os fatos sejam mais esclarecidos”, resumiu Marco Aurélio Mello, relator da ação ${ }^{49}$.

administrativa e financeira do Poder Judiciário e do cumprimento dos deveres funcionais dos juízes, cabendo-lhe, além de outras atribuições que lhe forem conferidas pelo Estatuto da Magistratura: [...] III - receber e conhecer das reclamações contra membros ou órgãos do Poder Judiciário, inclusive contra seus serviços auxiliares, serventias e órgãos prestadores de serviços notariais e de registro que atuem por delegação do poder público ou oficializados, sem prejuízo da competência disciplinar e correicional dos tribunais, podendo avocar processos disciplinares em curso e determinar a remoção, a disponibilidade ou a aposentadoria com subsídios ou proventos proporcionais ao tempo de serviço e aplicar outras sanções administrativas, assegurada ampla defesa; [...]; V - rever, de ofício ou mediante provocação, os processos disciplinares de juízes e membros de tribunais julgados há menos de um ano".

48 Sobre a autonomia administrativa do Poder Judiciário, a Constituição de 1988 dispunha: "Art. 96. Compete privativamente: I aos tribunais: a) eleger seus órgãos diretivos e elaborar seus regimentos internos, com observância das normas de processo e das garantias processuais das partes, dispondo sobre a competência e o funcionamento dos respectivos órgãos jurisdicionais e administrativos"; e "Art. 99. Ao Poder Judiciário é assegurada autonomia administrativa e financeira".

49 BRÍGIDO, Carolina. No país da impunidade, STF em crise não consegue decidir sobre punição a juízes. Reação da opinião pública impede tribunal de retirar poderes do CNJ. O Globo, Rio de Janeiro, 29 set. 2011. p. 1.
De fato, o pedido de cautelar veiculado na ação foi pautado 13 (treze vezes), mas encerrou-se o ano judiciário sem que viesse a ser apreciado pelo $\mathrm{STF}^{50}$. Em virtude disso, o relator do feito, o Ministro Marco Aurélio, valeu-se de dispositivo regimental que o autorizava a apreciar monocraticamente a questão e deferiu a liminar, afirmando a competência meramente subsidiária do Conselho ${ }^{51}$. A decisão gerou, então, uma verdadeira comoção $^{52}$. A reação foi imediata: manifestações contrárias à decisão foram publicadas e atos de apoio ao CNJ foram organizados por entes da sociedade civil ${ }^{53}$. Veja-se como foi noticiada a reação da Ordem dos Advogados do Brasil $(\mathrm{OAB})$ à decisão:

Em seu discurso, Ophir [Presidente da OAB] afirmou ainda que não é só a questão da competência do CNJ que está em jogo. "É a visão conservadora de um lado, arraigada na ideia de tribunais soberanos, de juízes soberanos, inalcançáveis, incensuráveis, inquestionáveis e impermeáveis, refratários inclusive ao calor humano do mundo que os cercam", salientou. Ele observou que a Resolução 135 do CNJ, contestada na Adin da AMB, uniformizando as normas relativas ao procedimento administrativo disciplinar, "teve a grandeza de evitar a degeneração dos processos nas mãos dos próprios juízes, o que na prática vinha acontecendo, de tal forma isolando o Judiciário da sociedade, como demonstram os resultados das inspeções realizadas nos tribunais pela Corregedoria Nacional do CNJ. ${ }^{54}$

Quando o Supremo Tribunal Federal retomou seu funcionamento, no início do ano de 2012, a cautelar foi levada à apreciação do plenário e, por uma decisão apertadíssima, de 6 a 5, acabou não confirmada, preva-

50 O processo constou da pauta dos dias 14, 21 e 28 de setembro, $5,13,19$ e 26 de outubro, $3,16,23$ e 30 de novembro, 7 e 14 de dezembro.

51 RISTF, art. 21: "São atribuições do relator: “[...]; IV - submeter ao Plenário ou à Turma, nos processos da competência respectiva, medidas cautelares necessárias à proteção de direito suscetível de grave dano de incerta reparação, ou ainda destinadas a garantir a eficácia da ulterior decisão da causa; V - determinar, em caso de urgência, as medidas do inciso anterior, ad referendum do Plenário ou da Turma".

52 RECONDO, Felipe. Liminar do STF esvazia poder do CNJ para investigar juízes. O Estado de São Paulo, São Paulo, 20 dez. 2011. 53 CONSELHO FEDERAL DA OAB. Ophir defende competência do CNJ para preservar moralidade e evitar impunidade. 31 jan. 2012. Disponível em: <http://www.oab.org.br/noticia/23385/ophirdefende-competencia-do-cnj-para-preservar-moralidade-e-evitarimpunidade $>$. Acesso em: 16 jun. 2013.

54 CONSELHO FEDERAL DA OAB. Ophir defende competência do CNJ para preservar moralidade e evitar impunidade. 31 jan. 2012. Disponível em: <http://www.oab.org.br/noticia/23385/ophirdefende-competencia-do-cnj-para-preservar-moralidade-e-evitarimpunidade>. Acesso em: 16 jun. 2013. 
lecendo, por consequência, a competência concorrente do CNJ para processar e julgar disciplinarmente os magistrados.

Meses mais tarde, quando o Ministro Cezar Peluso se desligou da Presidência da Corte, em virtude de sua aposentadoria compulsória, o próprio reconheceria, em entrevista, que, no julgamento sobre a competência concorrente do CNJ, a Corte sofrera uma pressão fortíssima da opinião pública, que esta influenciara no desfecho da ação e que, em outras circunstâncias, é possivel que a questão tivesse sido decidida de modo divers $0^{55}$. Manifestou-se, ainda, preocupado com uma tendência que via no Tribunal de buscar se alinhar com a opinião popular, quando o papel de uma corte constitucional, do ponto de vista ortodoxo, seria decidir contra a maioria, se isso fosse necessário para preservar direitos constitucionais ${ }^{56}$. Vale a pena a leitura do trecho da entrevista transcrito abaixo:

\section{VALOR: O debate sobre os poderes do $\mathrm{CNJ}$ não foi uma crise no Judiciário?}

PELUSO: Eu acho que tivemos uma má coincidência. Decidir sobre aquela questão num momento de efervescência em relação à discussão sobre os limites das competências constitucionais do CNJ. Se isso tivesse sido decidido num outro clima o resultado poderia ter sido diverso. Houve certa pressão...

VALOR: Um clima de que ninguém investiga juízes no Brasil?

PELUSO: Isso. De intimidação contra os ministros do STF que estavam aparecendo na opinião pública como se fossem corporativistas, o que está longe de corresponder à verdade. Se essa decisão tivesse sido tomada num outro clima o resultado seria diferente. ${ }^{57}$

Os casos antes narrados demonstram que, por um lado, o Legislativo, muito embora composto por representantes eleitos pelo voto popular, nem sempre deci-

55 BASILE, Juliano. Peluso propõe esforço concentrado para julgar mensalão neste ano. Valor. São Paulo, p. A16, 19 abr. 2012, Política. Disponível em: <http://www2.senado.leg.br/bdsf/handle/id/470853>. Acesso em: 16 jun. 2013.

56 SOUZA, André de; BRÍGIDO, Carolina. Ministro Cezar Peluso ataca, alvos não revidam críticas. O Globo, Rio de Janeiro, 19 abr. 2012, p. 15. Disponível em: <http://oglobo.globo.com/brasil/ministro-cezar-peluso-ataca-mas-alvos-nao-revidam-criticas-4683776>. Acesso em: 16 jun. 2013. Segundo a reportagem, o ministro Peluso teria declarado textualmente: "Há uma tendência dentro da Corte em se alinhar com a opinião pública".

57 BASILE, Juliano. Peluso propõe esforço concentrado para julgar mensalão neste ano. Valor, São Paulo, 19 abr. 2012, p. A16. Política. Disponível em: <http://www2.senado.leg.br/bdsf/handle/id/470853>. Acesso em: 16 jun. 2013. de de forma convergente com o que pensa a maioria da população. Por outro lado, indicam também que o Supremo Tribunal Federal não é livre para decidir de forma contrária ao pensamento dominante na comunidade, a despeito de se compor por juízes vitalícios, cuja permanência no cargo independe da aquiescência de quaisquer dos poderes ou da opinião pública. Algumas das razões pelas quais o legislador pode se afastar da vontade popular já foram enfrentadas acima. É válido perquirir, igualmente, por que uma corte constitucional pode se sentir compelida a observá-la.

\section{RAZÕES DA CONVERGÊNCIA ENTRE AS CORTES CONSTITUCIONAIS E A OPINIÃO PÚBLICA: REFLEXÕES A PARTIR DA LITERATURA ESTRANGEIRA}

Uma consulta à literatura estrangeira permite a identificação de múltiplas causas explicativas da influência da opinião pública sobre as decisões das cortes constitucionais e/ou sobre os votos dos seus membros ${ }^{58}$. Afirma-se, primeiramente, que cortes que têm membros selecionados por um processo que épolítico são sensiveis à opinião pública porque o modo de escolha dos juízes favorece a nomeação de profissionais que trafegam na fronteira entre o jurídico e o político e que, por conseguinte, são influenciáveis pela política ${ }^{59}$.

Essa primeira explicação permitiria a formulação da seguinte hipótese: como os ministros do STF são indicados pelo Chefe do Executivo e aprovados pelo Senado, eles refletem, de alguma maneira, a ideologia de quem os selecionou, as tendências dominantes no meio político que os elegeu ou na comunidade de um modo geral, por serem profissionais permeáveis a ela ${ }^{60}$.

58 Obviamente, não se pretende importar conclusões extraídas de sistemas, tradições e culturas distintas. Os estudos estrangeiros são utilizados apenas com finalidade especulativa, tendo em vista que as obras nacionais sobre a matéria são ainda escassas.

59 No modelo norte-americano, que tem um processo de seleção dos justices da Suprema Corte semelhante ao brasileiro (indicação chefe do Executivo e aprovação pelo Senado), essa hipótese foi formulada por: DAHL, Robert A. Decision-making in a democracy: the Supreme Court as a national policy-maker. Journal of Public Law, v. 6, p. 570 e ss, 1957.

60 A tese é contestada com base em dois argumentos. Em primeiro lugar, observa-se que, mesmo que os presidentes procurem nomear juízes que se alinhem com as suas convicções fundamentais, nada garante que tal magistrado não os surpreenderá com decisões que conflitam com tais convicções. Há, ainda, na literatura, estudos que indicam que as cortes constitucionais são sensíveis a alterações ide- 
Se assim não fosse, não transitariam bem nos ambientes responsáveis por sua escolha. Entretanto, como já demonstrado, as tendências dominantes no meio político e na comunidade podem divergir ${ }^{61}$. Além disso, estudos empíricos já demonstraram que o fato de a maioria dos ministros do STF ter sido selecionada por presidentes de um mesmo partido não garante que decidirão de forma alinhada com os interesses deste último ${ }^{62}$.

Uma outra hipótese que poderia ser formulada: o processo seletivo que vigora no Brasil leva à escolha de operadores do Direito não apenas qualificados tecnicamente, mas que igualmente transitam bem entre as altas autoridades que poderiam apoiar uma "candidatura ao STF". Essas autoridades e os ambientes que frequentam são extremamente sensíveis à percepção popular, e aqueles que logram maior êxito neles tendem a refletir esse padrão ${ }^{63}$.

Uma segunda razão identificada na literatura para a convergência entre as decisões judiciais proferidas por cortes constitucionais e o pensamento da maioria da população diz respeito ao fato de que os ministros são cidadãos como quaisquer outros e, por isso, encontram-se expostos aos mesmos movimentos sociais e às mesmas influências ideologicas e políticas que interferem sobre o comportamento do resto da população. Disso decorreria uma inclinação a decidir de acordo com tais influências, sobretudo em temas que atraem a atenção popular, como é o caso do combate à impunidade dos poderosos, ao corporativismo e à perpetuação do status quo ${ }^{64}$.

ológicas na comunidade independentemente de haver mudança em sua composição. O fato de os juízes se alinharem a mudanças na opinião pública, mesmo quando já empossados em cargos vitalícios, alega-se, indicaria a existência de um vínculo direto entre o sentimento popular e as decisões da corte constitucional. V. GILES, Micheal W; BLACKSTONE, Bethany; VINING, Richard L. The Supreme Court in American democracy: unraveling the linkages between public opinion and judicial decision-making. Journal of Politics, v. 70, p. 293-306, 2008; MARSHALL, Thomas R. Public opinion and the Supreme Court. Nova York: State University of New York Press, 2008. p. 116-119.

61 Basta rever os três primeiros casos examinados acima.

62 MELLO, Patrícia Perrone Campos. Nos bastidores do Supremo Tribunal Federal. Rio de Janeiro: Forense, 2015. p. 77-87 e 322-369.

63 BARROSO, Luís Roberto. Constituição, democracia e supremacia judicial: direito e política no Brasil contemporâneo. p. 33. Disponível em:<http://www.luisrobertobarroso.com.br/pt/noticias/constituicao_democracia_e_supremacia_judicial_11032010.pdf>. Acesso em: 2 jul. 2012.

64 LAIN, Corinna Barrett. Upside-down judicial review. Social Science Research Network, [Rochester], 12 Jan. 2012. p. 492013 e ss. Disponível em: <http://ssrn.com/abstract=1984060>. Acesso em: 27 set. 2013; SUNSTEIN, Cass. A constitution of many minds. Nova Jersey: Princeton University Press, 2009. p. 142 e ss.; GILES, Micheal
Essa hipótese, poderia ser polemizada a partir dos casos do CNJ narrados acima. Havia neles um clamor popular por mudança, pela ampliação do controle do Judiciário e pela superação da impunidade de magistrados faltosos. Entretanto, havia outras influências concorrentes, como a apreensão da magistratura de que o Conselho representasse uma forma de limitar a independência do Judiciário e a pressão exercida pela AMB sobre a Corte. Parte dos ministros do STF eram juízes de carreira. É possível que tais ministros não fossem indiferentes à repercussão das suas decisões junto a seus colegas. O quórum de 6 a 5, pelo qual se decidiu manter a competência disciplinar concorrente do CNJ no julgamento cautelar, sugere que a comunidade e a magistratura representavam influências concorrentes e igualmente poderosas sobre a Corte.

Afirma-se, igualmente, que as cortes, ao decidirem, avaliam os impactos que determinado entendimento pode produzir sobre a sua legitimidade e credibilidade perante a comunidade $\mathrm{e}$ evitam se submeter a certos desgastes. Isso ocorreria porque o Judiciário, paradoxalmente, dependeria dos demais poderes e/ou do apoio da própria opinião pública para fazer valer suas decisões e sua independência no longo prazo. É que o Judiciário não é dotado de poder de coerção. Depende do Executivo para fazer cumprir seus julgados. Não dá a palavra final sobre o seu orçamento, sobre a remuneração dos juízes ou dos serventuários da justiça. Depende, neste ponto, do Legislativo. Executivo e Legislativo são poderes reativos à opinião pública. Portanto, há ônus institucionais importantes em contrariá-la também para o STF ${ }^{65}$.

W.; BLACKSTONE, Bethany; VINING, Richard L. The Supreme Court in American democracy: unraveling the linkages between public opinion and judicial decision-making. Journal of Politics, [West Nyack], v. 70, p. 293-306, 2008; BRENNER, Saul; WHITMEYER, Joseph M. Strategy on the United States Supreme Court. Nova York: Cambridge University Press, 2009. p. 134.

65 V. BICKEL, Alexander M. The least dangerous branch. 2. ed. New Haven: Yale University Press, 1986; FRIEDMAN, Barry. The will of the people: how public opinion has influenced the Supreme Court and shaped the meaning of the Constitution. Nova Iorque: Farrar, Strauss and Giroux, 2009. p. 375; PRITCHETT, C. Herman. Congress versus the Supreme Court: 1957-1960. Minneapolis: University of Minnesota, 1961; EGAN, Patrick J.; CITRIN, Jack. Opinion leadership, backlash, and delegitimation: Supreme Court rulings and public opinion. Social Science Research Network, Rochester, ago. 2009. Disponível em: < http:// ssrn.com/abstract=1443631>. Acesso em: 27 set. 2013; BARROSO, Luís Roberto. Constituição, democracia e supremacia judicial: direito e política no Brasil contemporâneo. p. 41-42. Disponível em: < http://www.luisrobertobarroso.com.br/pt/noticias/constituicao_democracia_e_supremacia_judicial_11032010.pdf>. Acesso em: 2 jul. 2012. 
Por consequência, quando uma corte constitucional cogita proferir uma decisão contramajoritária, seus juízes, afirma-se, fazem uma avaliação de custo-benefício sobre as consequências negativas de tal decisão. Ao longo de sua história, uma corte produz decisões majoritárias e contramajoritárias. Através das primeiras, constrói uma imagem positiva perante a população, adquire e acumula capital político. Por meio das últimas, consome este capital. Isso não significa que não deve ou que não pode tomar decisões contramajoritárias. Ao contrário, essa é uma das justificativas para atribuir o controle da constitucionalidade a juízes que não foram eleitos pelo voto popular: a necessidade de preservar alguns direitos contra decisões arbitrárias da maioria. Entretanto, como o capital político da corte é limitado e como seus integrantes sabem disso, tendem a usá-lo com parcimônia; nos casos que consideram verdadeiramente relevantes; e desde que acreditem que o resultado alcançado justifica o desgaste político que se sofrerá ${ }^{66}$.

Além disso, quando eventualmente uma corte constitucional opta por proferir uma decisão que entra em confronto com um pensamento muito consolidado na comunidade, é possível que um "diálogo social" estabelecido a partir da reação desta última a seu julgado faça com que recue e se realinhe ao sentimento popular. Isso ocorre porque nenhum poder, por mais independente que seja, é capaz de decidir sistematicamente em desacordo com a comunidade e, ainda assim, preservar a sua estabilidade institucional. Para não se fragilizar e, portanto, para não abrir mão do valor maior de poder influenciar nos rumos do Direito no longo prazo, até mesmo uma corte constitucional pode precisar ceder à uma vontade popular muito contundente ${ }^{67}$.

Talvez os casos que envolveram o Conselho Nacional de Justiça sejam ilustrativos dessa hipótese. É possível que a constitucionalidade de um órgão de controle do Judiciário composto por representantes de outros poderes e a atribuição de competência concorrente a este órgão para punir magistrados não fossem os entendimentos que a maioria dos membros do STF na ocasião preferia afirmar. Mas não é impensável que tenham concluído que manter uma decisão contra o $\mathrm{CNJ}$ nesses

66 EASTON, David. A re-assessment of the concept of popular support. British Journal of Politics Science, n. 5, p. 435 e ss, 1975,.

67 FRIEDMAN, Barry. The will of the people: how public opinion has influenced the Supreme Court and shaped the meaning of the Constitution. Nova York: Farrar, Strauss and Giroux, 2009. p. 379 e ss.; FRIEDMAN, Barry. The politics of judicial review. Texas Law Review, Austin, v. 84, p. 326, 2005; e FRIEDMAN, Barry. Mediated popular constitutionalism. Michigan Law Review, v. 101, p. 2615 e ss, 2003. casos ensejaria um ônus demasiadamente alto para o Supremo, comprometendo sua credibilidade para decidir outras matérias importantes no futuro.

Por fim, a própria relação que os ministros pessoalmente estabelecem com a opinião pública pode ampliar os efeitos desta sobre os julgamentos do Tribunal. Em um julgamento polarizado, em que metade dos membros tende a votar num sentido e a outra metade, no sentido inverso, se o magistrado que funcionar como o "fiel da balança" (swing justice) for muito sensível à vontade popular, esta acabará por prevalecer.

O juiz, por sua vez, pode ser sensível à opinião pública por múltiplas causas. Pode, pessoalmente, considerá-la um grupo de referência relevante para decidir; pode ter o reconhecimento por parte da população como objeto de desejo ou de vaidade; pode até mesmo nutrir silenciosamente a aspiração a ingressar na política majoritária $^{68}$. Não é incomum a mídia brasileira cogitar da candidatura de magistrados com maior projeção junto ao público para a presidência da República ${ }^{69}$ e aqueles rigorosos em matéria penal gozam de especial popularidade junto à mídia e aos cidadãos ${ }^{70}$.

\section{O STF E A JUSTIÇA ESPETÁCULO}

A última consideração traz, contudo, algumas inquietações. De fato, os cidadãos sabem muito pouco

68 POSNER, Richard. How judges think. Cambridge: Harvard University, 2008; POSNER, Richard. What do judges maximize? The same thing everybody else does. Supreme Court Economic Review, Nova Iorque, v. 3, p. 1, 1993; SCHAUER, Frederick. Incentives, reputation and the inglorious determinants of judicial behavior. Cincinnati Law Review, v. 68, p. 615-636, 2000; BAUM, Lawrence. Judges and their audiences: a perspective on judicial behavior. Nova Jersey: Princeton University, 2008. p. 28; ASHENFELTER, Orley; EISENBERG, Theodore; SCHWAB, Stewart. Politics and the judiciary: the influence of judicial background on case outcomes. Journal of Legal Studies, v. 24, p. 257, 1995; GOFFMAN, Irving. The presentation of self in everyday life. Nova Iorque: Double Day, 1959; WALSH, Katherine Cramer. Talking about politics: informal groups and social identity in American life. Chicago: The University of Chicago Press, 2004. p. 8-91.

69 SOFIA, Julianna. Cármen Lúcia aproxima STF da população e surge como nome para 2018. Folha de São Paulo, nov. 2016; BRUNO, Cássio; AMORIM, Silvia. Barbosa na pesquisa. Presidente do STF diz que está lisonjeado. O Globo, 2 jul. 2013, p. 6.

70 SCHREIBER, Simone. A publicidade opressiva de julgamentos criminais. Rio de Janeiro: Renovar, 2008; DINIZ, Laura; MARQUES, Hugo. O triunfo da justiça. Os ministros do Supremo Tribunal Federal condenam os mensaleiros, denunciam a corrupção e caem nas graças dos brasileiros, carentes de referências éticas. Veja, ano 45, n. 41, p. 71, 10 out. 2012. 
sobre o que efetivamente ocorre ou sobre o que se discute no âmbito de poder público. A maior parte dos fatos e dos debates chegará a seu conhecimento apenas se grupos intermediários entre as autoridades e a população os levarem a público. O principal desses grupos é a imprensa. É através dos jornais, do rádio, da televisão e das redes sociais que a maior parte das pessoas toma conhecimento sobre as principais questões que interessam ao país.

Para que um assunto chegue ao conhecimento da população, é preciso, primeiramente, que um jornalista, um repórter ou alguém com amplo acesso à rede tome conhecimento a seu respeito. Em seguida, é preciso que se considere o assunto ou o fato merecedor de notícia. Um ser humano fará sempre o primeiro filtro a respeito da informação. Aquelas que não considerar relevantes - a maior parte delas - não será sequer levada ao conhecimento geral. Uma vez interessado em determinada questão, o jornalista a reportará segundo as suas próprias percepções. Todo relato é, em alguma medida, uma versão produzida pela subjetividade de quem relata. Todas as pessoas são altamente influenciadas por suas visões de mundo, por suas experiências pretéritas, por seu background, pelos grupos com os quais se identificam, pela fé que professam, pelos valores pelos quais estão dispostas a lutar ${ }^{71}$.

Os jornalistas e os repórteres geralmente têm patrão. Trabalham para jornais, para revistas, para canais de televisão, para pessoas jurídicas com fins lucrativos e se pautam por uma determinada linha editorial.

Os meios de comunicação, por sua vez, vivem de seus anunciantes e daqueles que consomem a sua programação. Quanto mais amplo o conjunto dos seus consumidores, maior a capacidade de vender anúncios e, por consequência, maior a sua prosperidade. Para alcançar mais consumidores, é preciso diversificar os temas, simplificar a linguagem e eleger fatos com potencial de interessar a uma grande massa de pessoas ${ }^{72}$. Histórias que envolvam autoridades, escândalos relacionados a pessoas públicas, crimes, corrupção, aborto, falência da saúde pública, comportamento sexual compõem um cardápio de curiosidades que atraem o interesse do pú-

71 LIPPMANN, Walter. Opinião pública. Petrópolis: Vozes, 2008. p. 271-309.

72 KEHL, Maria Rita. Muito além do espetáculo. In: NOVAES, Adauto (Org.). Muito além do espetáculo. São Paulo: Senac, 2004. p. 234 e ss. blico. Aquele que libera em primeira mão a notícia, frui dos benefícios do "furo de reportagem". Leva os louros, vende os jornais, colhe os anunciantes, conquista os consumidores.

Nessas condições, não se pode perder muito tempo apurando fatos, verificando a credibilidade de fontes, confirmando responsabilidades. É preciso liberar rapidamente a matéria. Uma vez divulgada, os que não foram obtiveram o "furo" estão atrasados. Precisam replicá-lo e, assim, manter seus consumidores informados sobre o que há de mais recente em termos de informação. Não há tempo a perder. É preciso fazê-lo rápidamente porque é assim que a concorrência agirá. $\mathrm{O}$ mesmo cidadão, em poucas horas, provavelmente será exposto à reiteração da mesma notícia por múltiplas mídias. "Quem conta um conto, aumenta um ponto" "73. A replicação da informação gera novos relatos. A repetição dá sensação certeza. E, assim, matérias meramente especulativas tendem a se tornar a única verdade possível ${ }^{74}$.

Para manter leitores, ouvintes e telespectadores interessados, a mídia os trata não apenas como cidadãos em busca de informações neutras, a respeito das questões de Estado relevantes, sobre as quais devem opinar, ou sobre os assuntos importantes apreciados pelo STF. Trata-os como consumidores em busca de entretenimento. É preciso conquistá-los, prendê-los, vinculá-los aos produtos que têm a oferecer. Para fazê-lo, procura-se criar uma identificação entre o cidadão, as matérias trazidas a seu conhecimento e os personagens nelas envolvidos ${ }^{75}$.

Com esse objetivo, os fatos e seus sujeitos são relatados e construídos com o recurso a estereótipos, tal como nas novelas. As notícias bombásticas trazem heróis destemidos, anti-heróis torpes, políticos corruptos, cidadãos simples idôneos, minorias humildes e oprimidas. Como consequência, o público passa a se relacionar com os fatos como os espectadores interagem com as novelas. A depender do rótulo que recebe um determinado personagem, de como seu papel se encaixa no enredo, a grande massa o terá por culpado ou inocente,

\footnotetext{
73 Provérbio popular.

74 MORETZSOHN, Sylvia. Jornalismo em "tempo real". O fetiche da velocidade. Rio de Janeiro: Revan, 2002. p. 70 e ss.

75 LIPPMANN, Walter. Opinião pública. Petrópolis: Vozes, 2008. p. 249 ss; FISS, Owen M. A ironia da liberdade de expressão. Estado, regulação e diversidade na esfera pública. Rio de Janeiro: Renovar, 2005. p. $99-134$.
} 
torcerá por seu fracasso ou por seu sucesso ${ }^{76}$. E se a decisão final não corresponder à expectativa construída pressionará pela correção do roteiro ou se indignará com seu desfecho ${ }^{77}$.

O modo de funcionar dos meios de comunicação de massa gera dois mecanismos que podem interferir gravemente sobre a opinião da população a respeito de determinado tema: o contágio informacional e o contágio reputacional ${ }^{78}$. O contágio informacional é gerado pela intensa reiteração da notícia, tende a gerar uma confirmação da certeza dos fatos mesmo quando ela não é plena e uma amplificação da percepção ao seu respeito. O contágio reputacional é produto da forma como os cidadãos, os estereótipos e os relatos interagem. Quanto mais uma determinada opinião é professada e acolhida pelos meios de comunicação, maior é a tendência a tornar-se amplamente dominante, em especial se for reproduzida por "âncoras", por formadores de opinião ${ }^{79}$. Quando esse tipo de contágio se efetiva, há uma inclinação dos indivíduos a simplesmente reproduzirem a percepção alheia, quer porque têm as mesmas dificuldades de compreensão, porque sua própria capacidade crítica foi afetada, porque não estão dispostos a expor um entendimento que será ferozmente desqualificado ou, ainda, porque temem as sanções sociais dele decorrentes ${ }^{80}$. Uma espécie de efeito manada se produz na população e, nessas circunstâncias, qualquer grupo pode ser levado a posições extremas, equivocadas e reforçadoras de preconceitos $^{81}$.

76 MORETZSOHN, Sylvia. Jornalismo em "tempo real". O fetiche da velocidade. Rio de Janeiro: Revan, 2002. p. 75-77.

77 SCHREIBER, Simone. A publicidade opressiva de julgamentos criminais. Rio de Janeiro: Renovar, 2008. p. 408.

78 SUNSTEIN, Cass R. Deliberative trouble? Why groups go to extremes. Yale Law Journal, v. 110, p. 71-119, out. 2000. p. 101-102; BON, Gustave. Psicologia das multidões. São Paulo: M. Fontes, 2008. p. 116-120. Cf., ainda, sobre o tema: FREUD, Sigmund. Psicologia de grupo e a análise do ego. In: FREUD, Sigmund. Além do princípio de prazer, psicologia de grupo e outros trabalbos (1990-1922). Obras psicológicas completas de Sigmund Freud: Edição Standard Brasileira. Rio de Janeiro: Imago, 1996. p. 81-156.

79 SUNSTEIN, Cass R. Infotopia: how many minds produce knowledge. Nova York: Oxford University, 2006. p. 25-43; SUNSTEIN, Cass R. Deliberative trouble? Why groups go to extremes. Yale Law Journal, v. 110, p. 71-119, out. 2000. p. 71.

80 BIKHCHANDANI, Sushil; HIRSHLEIFER, David; WELCH, Ivo. Learning from the behavior of others: conformity, fads, and informational cascades. Journal of Economic Perspectives, v. 12, n. 3, p. 151, 1998.

81 SUNSTEIN, Cass R. A Constitution of many minds: why the founding document doesn't mean what it meant before. Nova Jersey: Princeton University, 2009. p. 169-170.
Os juízes, como qualquer cidadão, estão sujeitos a tais mecanismos. Como todas as pessoas, buscam o reconhecimento e temem o isolamento. É ínfimo o nível de informação direta de que se dispõe sobre o comportamento de um magistrado, sobre as decisões que profere ou sobre as suas opiniões. Os julgados que ganham visibilidade são levados a público sobretudo pela imprensa. A mídia é um poderoso intermediário entre os juízes de uma corte constitucional e todos os grupos com os quais se importam: os amigos, os colegas de profissão, a comunidade jurídica, os movimentos sociais e, sobretudo, a opinião pública ${ }^{82}$. A percepção geral a seu respeito não emerge necessariamente de forma espontânea. Sujeita-se a um processo de animação social que pode ser edificante ou devastador. Assim como a população em geral, os integrantes de uma corte são expostos e vulneráveis ao contágio informacional e ao contágio reputacional.

O Supremo Tribunal Federal tem julgado casos de grande relevo para o país, a exemplo do impeachment da presidente da República ${ }^{83}$, do afastamento do presidente da Câmara dos Deputados ${ }^{84}$ e da prisão preventiva de Senador da República ${ }^{85}$ acusado de obstar investigação federal sobre corrupção envolvendo a cúpula da política. As causas que examina tratam sobre questões determinantes para o futuro do país; atraem a atenção da mídia e o interesse de seus consumidores; suscitam preconceitos e provocam estereótipos.

Os julgamentos do pleno do STF são televisionados ao vivo. A corte comunica-se institucionalmente com o público pela Rádio Justiça, está presente nas redes sociais, recebe manifestações por meio da central do cidadão, convoca audiências públicas para debater temas de relevo sob a sua apreciação e admite a participação de entidades da sociedade civil nos feitos que aprecia, a fim de ampliar o debate neles travados. As palavras e os atos dos ministros são meticulosamente acompanhados pela mídia. Há enorme interesse a respeito das suas opiniões. Suas ações têm grande visibilidade. Suas declarações e votos geram ondas de comentários nas redes sociais. Seus entendimentos são avaliados pela imprensa e julgados pelo público; a mesma imprensa, os mesmos juízes

82 BAUM, Lawrence. Judges and their audiences. A perspective on judicial behavior. Nova Jersey: Princeton University, 2008. p. 140.

83 ADPF 378 MC, Rel. p/ o acórdão Min. Luís Roberto Barroso, DJe, 8 mar. 2016.

84 AC 4070 Ref., Rel. Min. Teori Zavascki, DJe, 12 maio 2016.

85 AC 4039 Ref., Rel. Min. Teori Zavascki, DJe, 27 nov. 2015. 
e o mesmo público que se sujeitam ao contágio informacional, ao contágio reputacional, ao efeito manada. De fato, o processo decisório e a vida dos ministros do Supremo têm sido tratados como um espetáculo. E a espetacularização da vida pode facilmente torná-la prisioneira da mídia, da opinião popular e do populismo judicial $^{86}$.

\section{Considerações finais}

Esse é o ponto de chegada desse ensaio. É importante, fundamental, em uma democracia, problematizar a legitimidade detida por juízes não eleitos pelo voto popular para proferir decisões que interferem fortemente sobre o processo político e que divergem da vontade da maioria. Essa é a discussão de que se tem ocupado tradicionalmente a academia, no que respeita à interação entre as cortes constitucionais e a opinião pública. Ocorre que talvez tais decisões contramajoritárias não sejam assim tão habituais. A literatura indica alguns fatores que podem ser fortemente indutores de uma convergência entre a opinião da maioria e os julgamentos das cortes constitucionais.

São eles: i) o critério político de seleção dos membros das cortes; ii) a sujeição dos ministros às mesmas influências, valores e tendências ideológicas a que se encontra sujeita a população de um modo geral; iii) a importância de preservar a credibilidade e a legitimidade do tribunal como instituição, tendo em vista que nenhum poder é capaz de se manter sistematicamente em desalinho com a opinião pública sem se colocar em risco; iv) a ocorrência de um diálogo social, por meio do qual decisões judiciais fortemente rejeitadas tendem a ser revistas; v) a preocupação dos ministros de uma suprema corte com a opinião pública como grupo de referência, seu desejo de reconhecimento, suas eventuais aspirações profissionais futuras.

86 MENDES, Conrado Hübner. Desempenho deliberativo de cortes constitucionais e o STF. In: MACEDO JUNIOR, Ronaldo Porto; BARBIERI, Catarina Cortada (Org.). Direito e interpretação. racionalidade e instituições. São Paulo: Saraiva, 2011. p. 353-361; PEREIRA, Jane Reis Gonçalves. O Judiciário e a opinião pública: riscos e dificuldades de decidir sob aplausos e vaias, 30 out. 2012. Disponível em: <http://www.osconstitucionalistas.com.br/o-judiciario-e-a-opiniao-publica-riscos-e-dificuldades-de-decidir-sob-aplausos-e-vaias>. Acesso em: 7 fev. 2014; SILVA, Virgílio Afonso da; MENDES, Conrado Hübner. Entre a transparência e o populismo judicial. Folha de São Paulo, São Paulo, maio, 2009. p. A3.
Ao menos nos casos de grande projeção, que movimentam estereótipos e preconcepções, que inflamam e mobilizam a população, o custo de proferir decisões divergentes da visão dominante na comunidade pode ser altíssimo para uma corte constitucional como instituição e para os seus ministros, profissional e pessoalmente. Há importantes desincentivos a elas que não devem ser desconsiderados.

Diante de tal quadro, é importante que, sem deixarmos de problematizar o aspecto contramajoritário das decisões do STF, passemos a problematizar igualmente suas decisões majoritárias. Não é porque uma decisão é momentaneamente majoritária que está certa. Não é porque é majoritária que é democrática; pode firmar-se em um quadro fático incompleto, pode ser produto de preconceito, pode decorrer do efeito contágio, do efeito manada e, em verdade, ferir os valores fundamentais que se deseja preservar. Convergir ou divergir da opinião pública não pode ser considerado um critério único ou estático de legitimação das decisões políticas ou judiciais.

A opinião pública erra. Os poderes de Estado erram. Seus membros erram. E como todas as instituições são falíveis, porque são construídas à imagem e semelhança de seus autores, não há segurança e nem justiça absolutas. A segurança e a justiça possíveis devem ser depositadas na fragmentação do poder político. $\mathrm{Na}$ divisão do poder entre instituições e entre agentes que funcionem com base em uma lógica distinta, sujeitos a limites e incentivos diversos. É fundamental evitar a preponderância de uma instituição, até mesmo quando ela aparentemente expressa o pensamento da maioria. É importante evitar a desqualificação das demais. É preciso refletir sobre a espetacularização dos julgamentos do Supremo Tribunal Federal.

\section{REFERÊNCIAS}

ASSOCIAÇÃO DOS MAGISTRADOS BRASILEIROS. Juizes Contra a Corrupção. Disponível em: <http:// www.amb.com.br/portal/docs/noticias/estudo_corrupcao.pdf>. Acesso em: 18 jun. 2013.

ASHENFELTER, Orley; EISENBERG, Theodore; SCHWAB, Stewart. Politics and the judiciary: the influence of judicial background on case outcomes. Journal of Legal Studies, v. 24, 1995. 
BARROSO, Luís Roberto. Constituição, democracia e supremacia judicial: direito e política no Brasil contemporâneo. p. 33. Disponível em: <http://www. luisrobertobarroso.com.br/pt/noticias/constituicao_ democracia_e_supremacia_judicial_11032010.pdf>. Acesso em: 2 jul. 2012.

BARROSO, Luís Roberto. O controle de constitucionalidade no direito brasileiro. São Paulo: Saraiva, 2004.

BASILE, Juliano. Peluso propõe esforço concentrado para julgar mensalão neste ano. Valor, São Paulo, 19 abr. 2012. Disponível em: <http://www2.senado.leg.br/ bdsf/handle/id/470853>. Acesso em: 16 jun. 2013.

BAUM, Lawrence. Judges and their audiences. A perspective on judicial behavior. Nova Jersey: Princeton University, 2008.

BICKEL, Alexander M. The least dangerous branch. 2. ed. New Haven: Yale University Press, 1986.

BIKHCHANDANI, Sushil; HIRSHLEIFER, David; WELCH, Ivo. Learning from the behavior of others: conformity, fads, and informational cascades. Journal of Economic Perspectives, v. 12, n. 3, 1998.

BON, Gustave. Psicologia das multidões. São Paulo: M. Fontes, 2008.

BRASIL. Câmara dos Deputados. MPV 489/2010. Brasília, 2010. Disponível em: <http://www.camara. gov.br/proposicoesWeb/fichadetramitacao?idProposic ao $=477274>$. Acesso em: 21 mar. 2016.

BRASIL. Constituição (1988). Constituição da República Federativa do Brasil de 1988. Disponível em: <http:// www.planalto.gov.br/ccivil_03/constituicao/constituicaocompilado.htm>. Acesso em: 24 mar. 2016.

BRASIL. Lei ñ 12.688, de 18 de julho de 2012. Disponível em: < http://www.planalto.gov.br/ccivil_03/_ato20112014/2012/lei/112688.htm>.

BRASIL. Lei no 12.745, de 19 de dezembro de 2012. Disponível em: <http://www.planalto.gov.br/ccivil_03/_ ato2011-2014/2012/Lei/L12745.htm>. Acessos em: 24 mar. 2016.

BRENNER, Saul; WHITMEYER, Joseph M. Strategy on the United States Supreme Court. Nova York: Cambridge University Press, 2009.

BRÍGIDO, Carolina. No país da impunidade, STF em crise não consegue decidir sobre punição a juízes. Reação da opinião pública impede tribunal de retirar poderes do CNJ. O Globo, Rio de Janeiro, 29 set. 2011.

BRUNO, Cássio; AMORIM, Silvia. Barbosa na pesquisa. Presidente do STF diz que está lisonjeado. O Globo, 2 jul. 2013.

CONSELHO FEDERAL DA OAB. Ophir defende competência do CNJ para preservar moralidade e evitar impunidade. 31 jan. 2012. Disponível em: <http://www.oab.org.br/ noticia/23385/ophir-defende-competencia-do-cnj-para-preservar-moralidade-e-evitar-impunidade $>$. Acesso em: 16 jun. 2013.

DAHL, Robert A. Decision-making in a democracy: the Supreme Court as a national policy-maker. Journal of $\mathrm{Pu}$ blic Law, v. 6, 1957.

DINIZ, Laura; MARQUES, Hugo. O triunfo da justiça. Os ministros do Supremo Tribunal Federal condenam os mensaleiros, denunciam a corrupção e caem nas graças dos brasileiros, carentes de referências éticas. Veja, ano 45, n. 41, 10 out. 2012.

DWORKIN, Ronald. Freedom's Law: The moral reading of the American constitution. Cambridge: Harvard University Press, 1996.

EASTON, David. A re-assessment of the concept of popular support. British Journal of Politics Science, n. 5, 1975.

EGAN, Patrick J.; CITRIN, Jack. Opinion leadership, backlash, and delegitimation: Supreme Court rulings and public opinion. Social Science Research Network, Rochester, ago. 2009. Disponível em: < http://ssrn.com/ abstract $=1443631>$. Acesso em: 27 set. 2013.

FISS, Owen M. A ironia da liberdade de expressão. Estado, regulação e diversidade na esfera pública. Rio de Janeiro: Renovar, 2005.

FREUD, Sigmund. Psicologia de grupo e a análise do ego. In: FREUD, Sigmund. Além do princípio de prazer, psicologia de grupo e outros trabalhos (1990-1922). Obras psicológicas completas de Sigmund Freud: Edição Standard Brasileira. Rio de Janeiro: Imago, 1996.

FRIEDMAN, Barry. Mediated popular constitutionalism. Michigan Law Review, v. 101, 2003.

FRIEDMAN, Barry. The politics of judicial review. Texas Law Review, Austin, v. 84, 2005.

FRIEDMAN, Barry. The will of the people: how public opinion has influenced the Supreme Court and shaped the meaning of the Constitution. Nova Iorque: Farrar, 
Strauss and Giroux, 2009.

GILES, Micheal W.; BLACKSTONE, Bethany; VINING, Richard L. The Supreme Court in American democracy: unraveling the linkages between public opinion and judicial decision-making. Journal of Politics, [West Nyack], v. 70, p. 293-306, 2008.

GOFFMAN, Irving. The presentation of self in everyday life. Nova Iorque: Double Day, 1959.

GUIMARÃES, José. Parecer apresentado em Plenário pelo Relator Designado para manifestar-se pela Comissão incumbida da apreciação da matéria: Medida Provisória no 527, de 2011. Disponível em: <http://www.camara.gov.br/ proposicoesWeb/prop_mostrarintegra?codteor $=8900$ $21 \&$ filename $=$ Tramitacao $-\mathrm{MPV}+527 / 2011>$. Acesso em: 23 mar. 2016.

KEHL, Maria Rita. Muito além do espetáculo. In: NOVAES, Adauto (Org.). Muito além do espetáculo. São Paulo: Senac, 2004.

LAIN, Corinna Barrett. Upside-down judicial review. Social Science Research Network, [Rochester], Jan. 2012. Disponível em: <http://ssrn.com/abstract $=1984060$. Acesso em: 27 set. 2013.

LIPPMANN, Walter. Opinião pública. Petrópolis: Vozes, 2008.

MARSHALL, Thomas R. Public opinion and the Supreme Court. Nova York: State University of New York Press, 2008.

MEGALE, Bela. Ministro Luís Roberto Barroso quer o fim do foro privilegiado. Folha de São Paulo, 23 maio 2016. Disponível em: <http://www1.folha.uol.com. br/poder/2016/05/1774158-ministro-do-stf-luis-roberto-barroso-quer-fim-do-foro-privilegiado.shtml $>$. Acesso em: 26 nov. 2016.

MELlO, Patrícia Perrone Campos. Nos bastidores do Supremo Tribunal Federal. Rio de Janeiro: Forense, 2015.

MENDES, Conrado Hübner. Desempenho deliberativo de cortes constitucionais e o STF. In: MACEDO JUNIOR, Ronaldo Porto; BARBIERI, Catarina Cortada (Org.). Direito e interpretação. racionalidade e instituições. São Paulo: Saraiva, 2011.

MENDES, Gilmar Ferreira; COELHO, Inocêncio Mártires; BRANCO, Paulo Gustavo Gonet. Curso de direito constitucional. São Paulo: Saraiva, 2010.

MILITÃO, Eduardo. Maioria é contra financiamen- to público de campanha. Uol, Congresso em foco, 26 jun. 2007. Disponível em: <http://congressoemfoco. uol.com.br/noticias/maioria-e-contra-financiamentopublico-de-campanha/>. Acesso em: 5 ago. 2015.

MORETZSOHN, Sylvia. Jornalismo em "tempo real". O fetiche da velocidade. Rio de Janeiro: Revan, 2002.

NICOLAU, Jairo. O sistema eleitoral de listas abertas no Brasil. Dados: Revista de Ciências Sociais, Rio de Janeiro, v. 49, n. 4, p. 689-720, 2006 a.

OPINIÃO CONSULTORIA. A imagem das instituições públicas brasileiras. Brasília, set. 2007. p. 13. Disponível em: <http://www.amb.com.br/docs/pesquisa/imagem_instituicoes.pdf $>$. Acesso em: 18 jun. 2013.

PASSARINHO, Natália. Câmara aprova por na Constituição doação de empresas a partidos. G1. Política. 25 maio 2015. Disponível em: <http://g1.globo.com/ politica/noticia/2015/05/camara-aprova-incluir-naconstituicao-doacao-de-empresas-partidos-politicos. html>. Acesso em: 6 maio 2015.

PEREIRA, Jane Reis Gonçalves. O Judiciário e a opinião pública: riscos e dificuldades de decidir sob aplausos e vaias. 30 out. 2012. Disponível em: <http://www. osconstitucionalistas.com.br/o-judiciario-e-a-opiniaopublica-riscos-e-dificuldades-de-decidir-sob-aplausose-vaias>. Acesso em: 7 fev. 2014.

PEREIRA, Rodolfo Viana; GELAPE, Lucas de Oliveira. $\mathrm{O}$ anacronismo do sistema proporcional de lista aberta no Brasil. Revista de Informação Legislativa, n. 205, p. 261-279, jan./mar. 2015.

POSNER, Richard. How judges think. Cambridge: Harvard University, 2008.

POSNER, Richard. What do judges maximize? The same thing everybody else does. Supreme Court Economic Review, Nova Iorque, v. 3, 1993.

PRITCHETT, C. Herman. Congress versus the Supreme Court: 1957-1960. Minneapolis: University of Minnesota, 1961.

RECONDO, Felipe. Liminar do STF esvazia poder do CNJ para investigar juízes. O Estado de São Paulo, São Paulo, 20 dez. 2011.

SCHAUER, Frederick. Incentives, reputation and the inglorious determinants of judicial behavior. Cincinnati Law Review, v. 68, p. 615-636, 2000.

SCHREIBER, Simone. A publicidade opressiva de julgamen- 
tos criminais. Rio de Janeiro: Renovar, 2008.

SILVA, Virgílio Afonso da; MENDES, Conrado Hübner. Entre a transparência e o populismo judicial. Folha de São Paulo, São Paulo, maio, 2009.

SOFIA, Julianna. Cármen Lúcia aproxima STF da população e surge como nome para 2018. Folha de São Paulo, nov. 2016.

SOUZA, André de; BRÍGIDO, Carolina. Ministro Cezar Peluso ataca, alvos não revidam críticas. O Globo, Rio de Janeiro, 19 abr. 2012, p. 15. Disponível em: $<$ http://oglobo.globo.com/brasil/ministro-cezar-peluso-ataca-mas-alvos-nao-revidam-criticas-4683776>. Acesso em: 16 jun. 2013.

SOUZA, André. Datafolha: Três em cada quatro brasileiros são contra o financiamento de campanha por empresas privadas. O Globo, Rio de Janeiro, 06 jul. 2015.
Disponível em: <http://oglobo.globo.com/brasil/ datafolha-tres-em-cada-quatro-brasileiros-sao-contrafinanciamento-de-campanha-por-empresas-privadas-16672767>. Acesso em 05 ago. 2015.

SUNSTEIN, Cass R. A Constitution of many minds: why the founding document doesn't mean what it meant before. Nova Jersey: Princeton University, 2009.

SUNSTEIN, Cass R. Deliberative trouble? Why groups go to extremes. Yale Law Journal, v. 110, p. 71-119, out. 2000.

SUNSTEIN, Cass R. Infotopia: how many minds produce knowledge. Nova York: Oxford University, 2006.

WALSH, Katherine Cramer. Talking about politics: informal groups and social identity in American life. Chicago: The University of Chicago Press, 2004. 
Para publicar na Revista de Direito Internacional, acesse o endereço eletrônico www.rdi.uniceub.br ou www.brazilianjournal.org.

Observe as normas de publicação, para facilitar e agilizar o trabalho de edição. 